\title{
Mechanisms tagging senescent red blood cells for clearance in healthy humans
}

\author{
Hans U. Lutz ${ }^{1}$ and Anna Bogdanova ${ }^{2 *}$ \\ 1 Department of Biology, Institute of Biochemistry, ETH Zurich, Zurich, Switzerland \\ 2 Vetsuisse Faculty, Zurich Center for Integrative Human Physiology (ZIHP), Institute of Veterinary Physiology, University of Zurich, Zurich, Switzerland
}

\author{
Edited by: \\ Lars Kaestner, Saarland University, \\ Germany \\ Reviewed by: \\ Paolo Arese, University of Torino, \\ Italy \\ Paola Bianchi, Fondazione IRCCS Cà \\ Granda, Italy \\ *Correspondence: \\ Anna Bogdanova, Vetsuisse Faculty, \\ Zurich Center for Integrative Human \\ Physiology (ZIHP), Institute of \\ Veterinary Physiology, University of \\ Zurich, Winterthurerstrasse 260, \\ CH-8057 Zurich, Switzerland \\ e-mail:annab@access.uzh.ch
}

This review focuses on the analysis and evaluation of the diverse senescence markers suggested to prime red blood cells (RBC) for clearance in humans. These tags develop in the course of biochemical and structural alterations accompanying RBC aging, as the decrease of activities of multiple enzymes, the gradual accumulation of oxidative damage, the loss of membrane in form of microvesicles, the redistribution of ions and alterations in cell volume, density, and deformability. The actual tags represent the penultimate galactosyl residues, revealed by desialylation of glycophorins, or the aggregates of the anion exchanger (band 3 protein) to which anti-galactose antibodies bind in the first and anti-band 3 naturally occurring antibodies (NAbs) in the second case. While anti-band 3 NAbs bind to the carbohydrate-free portion of band 3 aggregates in healthy humans, induced anti-lactoferrin antibodies bind to the carbohydrate-containing portion of band 3 and along with anti-band 3 NAbs may accelerated clearance of senescent RBC in patients with anti-neutrophil cytoplasmic antibodies (ANCA). Exoplasmically accessible phosphatidylserine (PS) and the alterations in the interplay between CD47 on RBC and its receptor on macrophages, signal regulatory protein alpha (SIRPalpha protein), were also reported to induce erythrocyte clearance. We discuss the relevance of each mechanism and analyze the strength of the data.

Keywords: human red blood cells, senescence, oxidative stress, hemoglobin, volume, vesicles, naturally occurring antibodies

\section{RED BLOOD CELL AGEING PARAMETERS AND THE CRITERIA OF EVALUATION}

Over the years many investigators of red blood cells (RBC) and their biochemical properties have centrifuged whole blood and used the RBC pellet without actively removing leucocytes/platelets, despite their simple and selective depletion has been introduced and recommended almost 40 years ago by Beutler et al. (1976). Many investigators did not add protease inhibitors to the buffers in which RBC and their membranes/extracts were further processed. The omission of these precautions has been and still is the major reason for deviating data. Omission of leucocyte removal has dramatic effects on cell-age sensitive RBC properties, like e.g., hemolysis, echinocytosis, vesicle release, phosphatidylserine (PS) exposure, and band 3 protein clusterization as carefully studied by Antonelou et al. (2012). Thus, leucocyte-depletion renders transfusion of red blood cell units stored for 3-7 days safe (Hod et al., 2011) and ameliorates the effects of long stored blood (Phelan et al., 2010). Hence, the value of a set of data is highly dependent on having taken the first and where possible also the second precaution and we have selected the data for the present review accordingly. Other contradictions originate from a misnomer, for example when authors claim to illustrate a RBC property as a function of cell age, but compare properties of energy-starved RBC with those of freshly isolated ones (Girasole et al., 2012; Kim et al., 2012).
$\mathrm{RBC}$ undergo multiple changes while they age in vivo. Some of these remain hidden within RBC, others affect the properties of the cell directly, like the loss of cations and the loss of membrane with some hemoglobin by vesiculation that result in an increased cellular density. An increased density implies a higher cell age as has been established by the decreased activities of a number of intracellular enzymes, measured in the lysate (hexokinase, aldolase, pyruvate kinase, glutamate-oxalacetate transaminase) (Table 1). The decrease in activity of multiple enzymes is, however, not linear with cell age, but almost exponential from reticulocytes to mature cells [for a comprehensive review of these aspects, see reference Clark (1988)]. This disadvantage has forced many investigators to use as cell age parameters properties that change almost linearly with cell age, as exoplasmically located acetylcholinesterase (Cohen et al., 1976), the RBC creatine content (Fehr and Knob, 1979; Lutz and Fehr, 1979) and the ratio of two Coomassie-blue stainable bands (the 4.1a/4.1b ratio) (Mueller et al., 1987). This ratio illustrates the extent of deamidation of band $4.1 \mathrm{~b}$ and luckily results in a change of the electrophoretic mobility of the protein in SDS polyacrylamide gels (Inaba and Maede, 1988). The separation of RBC according to their density has been achieved first by centrifuging RBC in an angle rotor where cells circulate to some extent in this highly viscous cell pellet (Murphy, 1973). With the availability of Stractan and Percoll it is the material that establishes a gradient or is arranged in a preformed gradient and allows RBC to better 
Table 1 | Changes in RBC properties associated with aging.

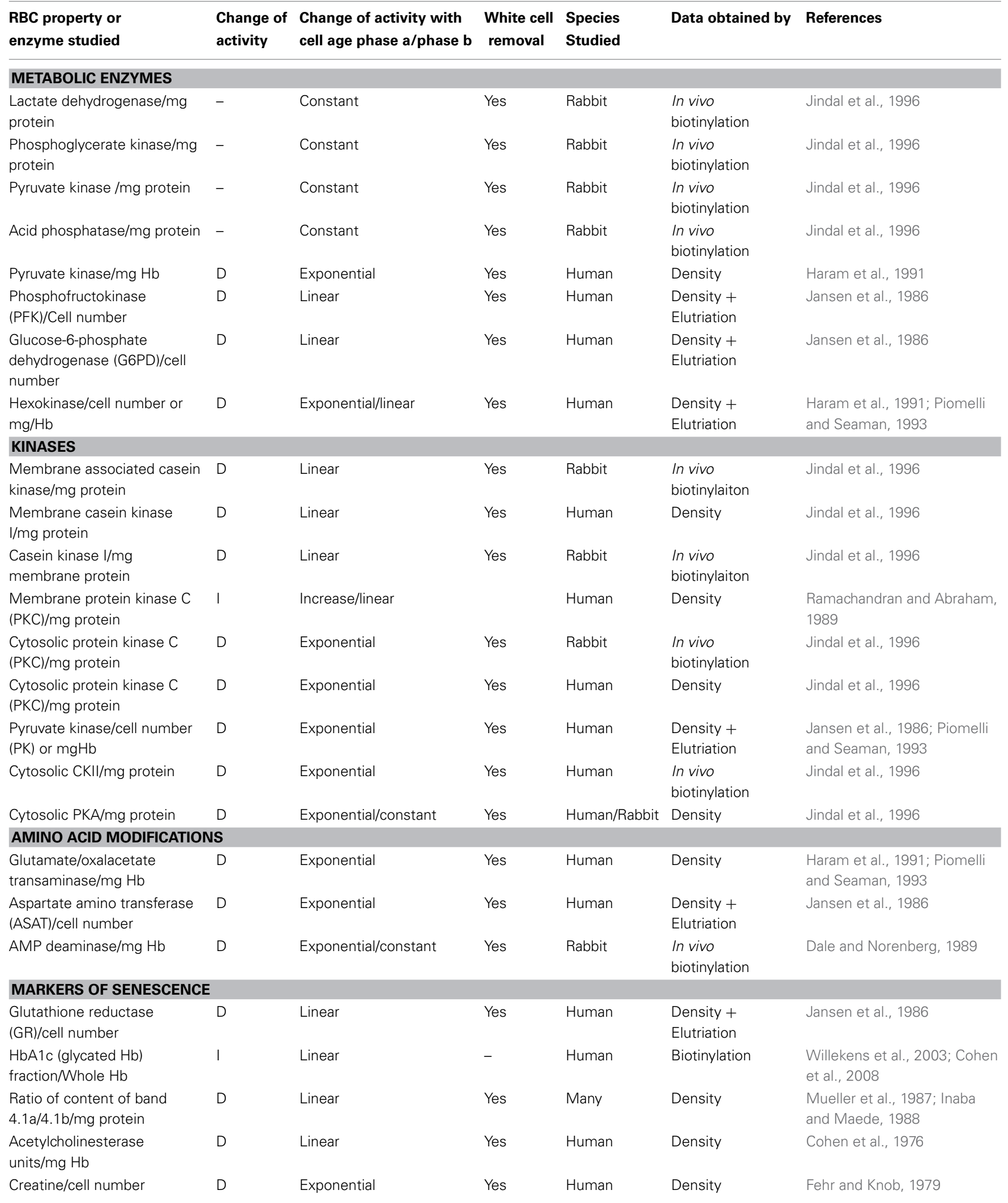

Changes in activity: I, increase and $D$, decrease; Phase a, reticulocytes mainly; phase b, mature RBC; Hb, hemoglobin; density, fractionation on the density gradient. 
migrate to their actual density (Clark, 1985; Lutz et al., 1992). Aside of density separation aging RBC have been separated from each other by size, using counterflow centrifugation (elutriation), a method that offers a limited yield of separated cells and may best be combined with a preceding density centrifugation (Bosch et al., 1992).

\section{THE CHANGES OCCURRING IN VIVO, WHEN LABELED RBC ARE RE-INTRODUCED INTO THE CIRCULATION}

By far the most direct method to study in vivo aging of RBC is their biotinylation by N-hydroxysuccinimide-biotin and analyzing the properties of the biotinylated RBC during their life span in circulation by collecting the labeled RBC on avidin at various times after injection (Suzuki and Dale, 1987; Christian et al., 1993). The biotin derivative was dissolved in DMSO and a diluted sample was injected intravenously into dogs after bleeding to enhance the portion of young RBC in the labeled population (Christian et al., 1993). In humans bleeding was not an option and biotinylation had to occur in vitro. Hence, the fraction of labeled RBC was rather small toward the end of the in vivo survival study by 110-126 days (Franco et al., 2013). Nevertheless, it has been possible for the first time to demonstrate that all in vivo aged, biotinylated human RBC that were recovered 126 days post injection had increased amounts of membrane-bound IgG, but were not enriched at all in exoplasmically exposed PS (Franco et al., 2013). Similar findings have earlier been reported for dogs having a similar RBC survival time as humans. By 110 days biotinylated RBC carried 7 fold higher amounts of autologous IgG per RBC and massively increased amounts of membrane bound globin (Rettig et al., 1999). Unexpectedly, the density of biotinylated RBC increased primarily during the first 4 weeks of in vivo aging, but not or less thereafter as revealed by using preformed density gradients (Franco et al., 2013). Similar results were obtained earlier for biotinylated sickle RBC (Franco et al., 1998). The authors blame the density-separation technique for the unexpected results and suggest that density centrifugation should be combined with elutriation to achieve a better separation according to cell age. However, it cannot be excluded that ex vivo biotinylation of $\mathrm{RBC}$ in diluted DMSO and several washes had altered the properties of RBC that were not leucocyte-depleted. Nevertheless, analogous results on aging $\operatorname{dog} \mathrm{RBC}$ confirm the unexpected finding. Dog RBC were in vivo biotinylated and revealed during survival signs of an accelerated aging in so far as a classical cell age parameter, the ratio of the band $4.1 \mathrm{a} / 4.1 \mathrm{~b}$ content had reached its maximum (full deamidation) in the biotinylated $\mathrm{RBC}$ portion long before the biotinylated $\mathrm{RBC}$ had reached their full survival time (Rettig et al., 1999). It may be possible that the findings were real, implying that a small fraction of aging RBC underwent a terminal density reversal by taking up sodium ions and water, as first described by Bookchin (Bookchin et al., 2000) and discussed in detail by Lew and Tiffert (2013). More studies are needed to clarify whether the terminal density reversal is induced by DMSO or the washes without white cell removal.

In the following chapters we address several parameters delineating age-related changes in healthy human RBC. Among them are oxidative stress, changes in cell volume and density, vesiculation, band 3 clustering, and binding of NAbs.

\section{THE ROLE OF OXIDATIVE STRESS IN RED CELL CLEARANCE}

Cell aging is intimately related to the changes in the balance between production of pro-oxidants and their removal by antioxidative enzymes and scavengers to which reduced glutathione (GSH), NADH, NADPH, and ascorbate belong. Gradual accumulation of irreversibly oxidized and denatured proteins, in particular hemoglobin, occurs with ageing (Rifkind and Nagababu, 2013). Changes in activity of multiple enzymes, loss or reorganization of several proteins as well as alterations in plasma membrane lipid composition occur gradually in RBC over 120 days in circulation and are mainly caused by oxidative modifications. De novo synthesis of both proteins and lipids is absent in mature RBC. Accordingly, oxidized and denatured proteins accumulate in aging $\mathrm{RBC}$ and even more so because aging $\mathrm{RBC}$ lose free radical scavengers (Bartosz, 1981).

\section{ANTIOXIDANT CAPACITY OF RBC}

Among the antioxidants which prevent oxidation of protein thiols are GSH, NADH, and NADPH. Of these three compounds the half-cell redox potential based on the ratio of GSH to oxidized glutathione (GSSG) is postulated to be a reliable marker of the intracellular redox state (Schafer and Buettner, 2001). Reduced glutathione does not cross the plasma membrane passively and de novo synthesis of GSH is the only source of GSH in RBC. Facilitated unidirectional efflux of GSSG from the RBC is mediated by an ATP(GTP)-dependent transporter (RLIP76) and multidrug resistance protein 1 (MRP1) (Srivastava and Beutler, 1969; Bobrowska-Hagerstrand et al., 2001; Sharma et al., 2001). The ability of RBC to synthesize GSH, the presence of enzymes involved in GSH synthesis and GSSG formation (Figure 1) have been demonstrated in RBC lysates (Sass, 1968). Two substrates for glutathione synthesis, cysteine and glycine, are transported into the cells whereas glutamate is produced from aspartate and alanine by aspartate aminotransferase and alanine aminotransferase. As follows from the scheme in Figure 1 de novo synthesis of glutathione requires ATP and its reduction from GSSG to GSH requires NADPH.

The intracellular non-protein thiol levels, of which GSH is the major species, decrease substantially during the transformation of reticulocytes to mature RBC, but their concentration remains rather constant thereafter (Magnani et al., 1983; Piccinini et al., 1995). In all these studies the average intracellular GSH and GSSG concentrations were assessed without discriminating between the ratio of GSH to GSSG in the pre-membrane pool and that in the cytosolic core. Since the oxidative stress in aging $\mathrm{RBC}$ is particularly severe at the membrane, these measurements may not precisely reflect the aging-related shift in the redox state. The activity of $\gamma$-glutamylcysteine synthetase and that of GSH synthetase, two major enzymes involved in glutathione synthesis (Figure 1), remain unchanged in RBC with increasing density (Minnich et al., 1971) and get suppressed only in the cells showing the highest density on the Stractan gradient (Piccinini et al., 1995). The activities of key glycolytic enzymes hexokinase, pyruvate kinase, and glucose-6-phosphate dehydrogenase, 


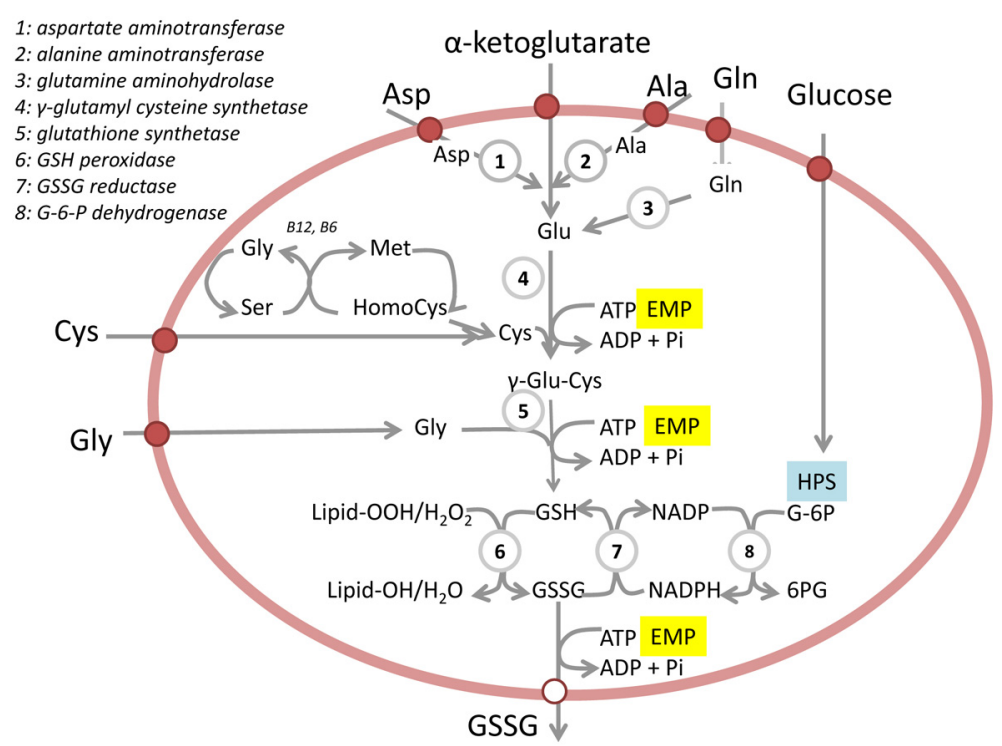

FIGURE 1 | Glutathione production and turnover in RBC. Schematically presented are substrate delivery, glutathione synthesis, and glutathione handling in RBC. EMP stands for Embden-Meyerhof pathway (anaerobic glycolysis). HPS denotes hexose monophosphate shunt (pentose phosphate pathway). G-6P and 6 PG stand for glucose-6-phosphate and 6-phosphogluconolacton respectively. Glu, Gln, Gly, Cys, Ala, and Asp stand for glutamate, glutamine, glycine, cysteine, alanine, and aspartate respectively. as well as that of aspartate aminotransferase which provides glutamate for GSH synthesis, were the highest in the low density fraction and progressively decreased with an increase in red cell density [(Fornaini et al., 1985; Jansen et al., 1986) and Table 1].

Glucose transport across the RBC membrane decreases with cell age (Bosman and Kay, 1990). Young (least dense) RBC metabolize 2.5 times more glucose than old ones. On the other hand, the amount of glucose utilized via the hexose monophosphate shunt does not show any age dependence. Intracellular ATP levels drop by $30-40 \%$ following the down-regulation of Embden-Meyerhof (EMP) pathway (Cohen et al., 1976; Magnani et al., 1983), contributing to a shortage of GSH production in the densest RBC fraction.

RBC possess an efficient enzymatic machinery to process and detoxify reactive oxygen and nitrogen species, including superoxide dismutase (SOD1), catalase, peroxidases as well as glutathione peroxidase, peroxiredoxin 2 and glutaredoxin 1, which reverse oxidative thiol modifications on proteins and preserve enzyme activities from oxidative inactivation. The activities of some of these anti-oxidants, such as SOD1 and catalase decline during aging (Bartosz et al., 1978; Bartosz, 1980, 1981; Bartkowiak et al., 1983). Even extracellular SOD isozymes, including mitochondrial SOD2 (presumably from the endothelial cells), participate in detoxifying free radicals that cause RBC oxidation, as SOD2deficient animals presented with higher rates of hemoglobin oxidation than controls (Mohanty et al., 2013). Further studies using knockout animals indicate that at least in rodents peroxiredoxin 2 and glutaredoxin 1 are the major enzymes detoxifying endogenous $\mathrm{H}_{2} \mathrm{O}_{2}$ in $\mathrm{RBC}$ (Lee et al., 2003; Johnson et al., 2010). Catalase on the contrary takes over detoxification of $\mathrm{H}_{2} \mathrm{O}_{2}$ produced externally (Johnson et al., 2010). RBC age-dependent changes in peroxiredoxin 2 and glutaredoxin 1 activities have not been studied yet.

\section{SOURCES OF OXIDATIVE EOUIVALENTS IN SENESCENT RBC}

Cell age-related oxidation is largely a membrane-localized event, because free radical generators are compartmentalized. Most of them are localized within the membrane or are attached to membrane proteins from the cytosolic side, whereas enzymes detoxifying them as well as low molecular weight thiols are randomly distributed within the cytosol.

Auto-oxidation of hemoglobin is considered to be the major source of superoxide anion production in senescent RBC. Reduction of dioxygen to $\mathrm{O}_{2}^{-}$is associated with the generation of methemoglobin. Ferric iron of methemoglobin is then reduced to the ferrous state by hemoglobin reductase which uses $\mathrm{NADH}$ as a substrate. The methemoglobin concentration was shown to increase linearly with increasing RBC density (Imanishi et al., 1985; Rettig et al., 1999). In vitro studies of the hemoglobin auto-oxidation revealed that the reaction is slow $\left(k=0.0115 \mathrm{~h}^{-1}\right)$ under normoxic conditions (Nagababu et al., 2002), but is facilitated dramatically upon partial deoxygenation (Abugo and Rifkind, 1994) and is maximal at $\mathrm{pO}_{2}$ of $1.33 \mathrm{kPa}$ (Rifkind et al., 2004). Deoxyhemoglobin readily binds to the cytosolic domain of band 3 (Walder et al., 1984). This suggests that the levels of deoxyhemoglobin at the membrane surface exceed those in the cytosol. Furthermore, aging of RBC is associated with an increase in spectrin-hemoglobin complexes (Snyder et al., 1983) which contribute to an increased rigidigty of senescent RBC in dense fractions (Fortier et al., 1988). Accumulation of hemoglobin at the membrane surface and its auto-oxidation results in production of superoxide anion. Two further classes of enzymes which contribute to superoxide production are $\mathrm{NADPH}$ 
oxidases of which several isoforms are present in RBC (George et al., 2013) and endothelial NO synthase which is present in human and mouse RBC (Kleinbongard et al., 2006) and produces $\mathrm{O}_{2}^{-}$when L-arginine levels are low (Mihov et al., 2009).

Superoxide anion has a half-life of $10^{-6} \mathrm{~s}$ and undergoes a number of transformations depending on the availability of $\mathrm{NO}$, superoxide dismutase (SOD), and $\mathrm{H}_{2} \mathrm{O}_{2}$. Interaction of $\mathrm{O}_{2}^{-}$with $\mathrm{NO}\left(k=4-610^{9} \mathrm{M}^{-1} \mathrm{~s}^{-1}\right)$ is four orders of magnitude faster than dismutation of $\mathrm{O}_{2}^{-}$to $\mathrm{H}_{2} \mathrm{O}_{2}$ catalyzed by SOD $\left(k=210^{5} \mathrm{M}^{-1} \mathrm{~s}^{-1}\right)$. Thus, formation of peroxynitrite $\left(\mathrm{ONOO}^{-}\right)$ from $\mathrm{O}_{2}^{-}$dominates over the transformation of $\mathrm{O}_{2}^{-}$to $\mathrm{H}_{2} \mathrm{O}_{2}$ catalyzed by superoxide dismutase if $\mathrm{NO}$ is available (Borges-Alvarez et al., 2012). Peroxynitrite generated in this manner is believed to be a potent mediator of oxidative stress in RBC (Minetti et al., 2008; Rifkind and Nagababu, 2013). However, aging of RBC is not associated with an accumulation of nitrated tyrosine, the product of peroxynitrite reacting with membrane proteins or hemoglobin (Kikugawa et al., 2000). It is suggested that peroxynitrite production in circulating $\mathrm{RBC}$ is minimal due to the low abundance of deoxyhemoglobin (Winslow and Intaglietta, 2008). Thus, the importance of peroxynitrite as a mediator of oxidative stress in aging RBC remains questionable. NO may be viewed as a scavenger of superoxide radicals and therefore as a member of the antioxidative defense system. This defense system is challenged particularly under hypoxic conditions when partially oxygenated hemoglobin prone to auto-oxidation is formed. Deoxygenated hemoglobin has been shown to function as nitrite reductase transforming nitrite to $\mathrm{NO}$ being itself oxidized to methemoglobin (Gladwin and Kim-Shapiro, 2008).

Endogenous hydrogen peroxide formed by a SOD1-catalysed reaction as well as exogenous $\mathrm{H}_{2} \mathrm{O}_{2}$, diffusing into $\mathrm{RBC}$ from plasma, may be detoxified by catalase or peroxidase. However, when ferrous or ferric ions are available they catalyze reactions known as Haber-Weiss cycle in which hydroxyl radicals (HO) are formed. The hydroxyl radical has a half-life of $10^{-9} \mathrm{~s}$ and is extremely reactive and pro-oxidative. Iron ions are becoming accessible in the pre-membrane space during the process of oxidation and denaturation of membrane-bound hemoglobin occurring with aging of RBC (Low et al., 1985). Hemichrome accumulation and binding to the cytosolic domain of band 3 protein is a hallmark of RBC senescence.

\section{TARGETS OF OXIDANTS}

$\mathrm{RBC}$ are one of the models of choice to monitor the effects of oxidants on proteins and lipids [e.g., Di Simplicio et al., 1998; Minetti et al., 2008]. However, relatively few studies refer to the monitoring of thiol modifications during ageing of $\mathrm{RBC}$ in vivo in healthy humans.

Hemoglobin, being the most abundant (98\% of total protein content) protein in $\mathrm{RBC}$, is the main generator of reactive oxygen species, the main target of oxidative damage and also a scavenger of free radicals. Detoxification of free radicals by hemoglobin is associated with the production of met-hemoglobin and oxidation of a single cysteine residue present in position 93 of the beta chain (Vitturi et al., 2013). The generated methemoglobin releases iron as $\mathrm{Fe}^{+3}$ in a chelatable form that can further propagate oxidative damage and induce binding of autologous IgG.
Ferrali et al. synthesized an aromatic iron-chelator and applied it to mice in which oxidative damage and iron release were induced by a phenylhydrazine treatment. The RBC from animals treated with the chelator were protected from oxidative damage and from binding of autologous IgG (Ferrali et al., 2000).

Band 3 protein is also a target of oxidation, particularly when it has formed complexes with oxidized and denatured hemoglobin, hemichrome (Mannu et al., 1995). Accumulation of membraneassociated oxidized hemoglobin is considered to be one of the major (but not the only) trigger of band 3 cluster formation (Low et al., 1985; Schlüter and Drenckhahn, 1986). In addition, oxidation is a trigger for activation of src tyrosine kinases (Mallozzi et al., 2001) and inhibition of tyrosine phosphatases (Zipser et al., 2002), resulting in a cumulative tyrosine hyperphosphorylation of membrane target proteins. The src kinases including syk and lyn kinases phosphorylate tyrosines 8 and 21 of the cytosolic domain of the band 3 protein, thereby facilitating formation of high-molecular-mass band 3 aggregates (Pantaleo et al., 2009). Oxidation and poor glycosylation of band 3 further facilitates clustering of this protein (Pantaleo et al., 2009). Its tyrosine phosphorylation markedly reduces the affinity of band 3 to ankyrin, causing destabilization of the band 3-cytoskeleton interaction, increases the lateral mobility of band 3 within the membrane and induces vesiculation (Ferru et al., 2011). Both srk kinases syk and lyn and the tyrosine phosphatase PTP1B are redox-sensitive, be it because they possess cysteine residues in the kinase domains or indirectly, because their activity is controlled by the redox- and calcium-sensitive phosphorylation steps mediated in particular by protein kinase C alpha (Bordin et al., 2005; Knock and Ward, 2011).

\section{CHANGES IN ACTIVITY OF ION TRANSPORTER DURING RBC SENESCENCE}

Transformation from reticulocytes to mature RBC and ageing of the latter is associated with radical re-organizations of the plasma membrane. Reduction in membrane surface by means of exocytosis during maturation of reticulocytes enables the cells to reduce or completely eliminate a number of receptors and ion transporters which play an active role in differentiation of erythroid precursor cells and are no longer required by mature RBC. Among the most well-known is the transferrin receptor. The number of copies per cell of $\mathrm{Na}, \mathrm{K}$-ATPase, $\mathrm{Na}$ /glycine transporter (Blostein and Grafova, 1987), nucleoside transporter, and $\mathrm{K}-\mathrm{Cl}$ cotransporter (Canessa et al., 1987; Ellory et al., 1991) is reduced and renders the cell less energy-demanding and more stable.

Several ion transporters that are not extruded in exosomes undergo an age-dependent inactivation. The activity of the Gardos channel is reduced with ageing (Tiffert et al., 2007). Similarly, the number of copies of N-methyl D-aspartate (NMDA) receptors, non-selective cation channels mediating $\mathrm{Ca}^{2+}$ uptake into RBC, also decreases with cell age (Makhro et al., 2013). Plasma membrane $\mathrm{Ca}^{2+}$ pump was also reported to decline with cell age (Lucas et al., 1988; Samaja et al., 1989).

These conclusions may not necessarily apply to all cells within the light, medium or dense fractions of RBC, but to a majority of them. Recently extreme heterogeneity in responses of RBC to glutamate and homocysteic acid (Makhro et al., 2010, 2013), 
prostaglandin E2 (Kaestner et al., 2004), LPA (Wagner-Britz et al., 2013) has been recognized. This heterogeneity results from the inter-cellular variability in abundance of the corresponding ion transport pathways [NMDA receptors, voltage-gated $\mathrm{Ca}^{2+}$ channels (Cav2.1), and LPA receptors] in RBC of healthy humans (Makhro et al., 2013; Wagner-Britz et al., 2013).

In the following section the impact of vesicle release on RBC aging will be discussed. This process of membrane loss also contributes to the increase in density of senescent cells.

\section{RELEASE OF MICROVESICLES AND NANOVESICLES FROM AGING RBC}

It is known for many years that senescent RBC are smaller, denser than young cells and have lost membrane and hemoglobin. Nevertheless, many investigators have quantified $\mathrm{N}$-acetylneuraminic acid (sialic acid) per young and per old $\mathrm{RBC}$ and then claimed that sialic acid decreased with cell age and the exposed remainder may act as a senescent cell marker, capable to trigger/mediate their selective removal (Gutowski et al., 1991; Bratosin et al., 1995). When the content of sialic acid was referred to a measure of the number of integral membrane proteins on young and old RBC, it was with $\pm 1.5 \%$ the same (Lutz and Fehr, 1979) and the cellular electrophoretic mobility remained unchanged during RBC aging (Luner et al., 1977). Despite the electrophoretic mobility remains unchanged, aging $\mathrm{RBC}$ loose a substantial portion of their membrane and content in form of microvesicles [reviewed in references Greenwalt (2006), Tissot et al. (2010)]. For a long time microvesicles were not in the focus of research, because those that are released in vivo are rapidly cleared and their relation to those from stored RBC was unclear. This situation has drastically changed since it has become obvious that the microvesicles from stored RBC have deleterious effects in transfused patients [for a review see Tissot et al. (2010)]. One of the deleterious effects comes from priming the respiratory burst of neutrophils (Jank and Salzer, 2011), which was, however, far more pronounced by microvesicles from RBC that were not leucocyte-depleted (Cardo et al., 2008).

The shedding of microvesicles from in vivo aging RBC was first illustrated by Dumaswala and Greenwalt (1984). By that time two types of in vitro RBC vesiculations had already been discovered as laboratory phenomena: Allan and coworkers had characterized vesicles released from $\mathrm{RBC}$ incubated with $\mathrm{Ca}^{2+}$ and ionophore (Allan and Michell, 1977) and Lutz and coworkers had studied vesicles released from ATP-depleted RBC (Lutz et al., 1977). Both types of vesicles contain hemoglobin and their membranes are enriched about 2 -fold in exoplasmic acetylcholinesterase, lack spectrin and ankyin, but retain the integral membrane proteins band 3 and glycophorin to about 50\%. Generation of microvesicles from stored RBC was also described in the 70s for storage in ACD (acid-citrate-dextrose) by Rumsby et al. (1977). These authors noted that stored RBC release hemoglobin-filled microvesicles that are depleted of spectrin, but contain integral membrane proteins. More recent data on the microvesicle release from stored and from $\mathrm{Ca}^{2+}$-loaded $\mathrm{RBC}$ that were leucocytedepleted, have yielded the following insights. At the onset of RBC storage the released microvesicles differ in composition from those released from $\mathrm{Ca}^{2+}$-loaded RBC. After prolonged storage (beyond 21 days), when the ATP-content of stored RBC decreases rapidly, the total amount of released vesicular proteins increases exponentially, reaching 10 times the amount by 50 days as compared to 14 days of storage and their composition becomes comparable to that of $\mathrm{Ca}^{2+}$-induced vesicles (Salzer et al., 2008). It is possible that this late change in amount and properties of microvesicles from stored RBC may be the major reason for why long stored blood units were primarily responsible for the deleterious effects in transfused patients.

$\mathrm{RBC}$ shrinkage and echinocytosis precede the release of microvesicles. It is known that budding and the release of microvesicles from $\mathrm{RBC}$ incubated with $\mathrm{Ca}^{2+}$ and ionophore are induced by the formation of diacylglycerol (Allan and Michell, 1977). Microvesicle generation from ATP-depleted RBC also correlates with the breakdown of polyphosphoinositides to diacylglycerol on the inner monolayer (Müller et al., 1981). The diffusible diacylglycerol partitions into the outer monolayer and thereby contributes to membrane budding. Nevertheless, membrane budding and shedding of microvesicles yet require other changes, because $10 \mathrm{mM}$ EDTA inhibited microvesicle release by $75 \%$ without affecting diacylglycerol production (Müller et al., 1981). Indeed, membrane budding is further dependent on exoplasmic exposure of phosphatidylserine (PS), a negatively charged phospholipid that normally is exclusively localized on the inner monolayer. Its exposure on the outer monolayer depends on activation of the scramblase by intracellular $\mathrm{Ca}^{2+}$, which is induced by ionophore (Nguyen et al., 2011) or by lysophosphatidic acid during RBC storage, but less upon prestorage leukodepletion (Nagura et al., 2013). It was further noted that prolonged storage of leucocyte-depleted RBC increases the susceptibility of RBC to stress-induced loss of phospholipid asymmetry. The effect was most pronounced for old RBC when experimentally evoked by a hyperosmotic shock, such that PS exposure increased 10-fold by 4 weeks storage and more so in old RBC (Bosman et al., 2011). Strong arguments in favor of PS exposure being required for microvesicle release come from (1) a bleeding disorder, the Scott syndrome, where RBC neither translocate PS across the membrane nor release microvesicles (Bevers et al., 1992) and (2) the finding that a specific inhibitor of the scramblase (R5421) inhibits both PS exposure and microvesicle release to more than 50\% (Gonzalez et al., 2009).

The regions on RBC that become enriched in diacylglycerol and PS are associated with lipid rafts. Lipid rafts are microdomains in the plasmamembrane, rich in cholesterol and glycosphingolipids and contain unique proteins that differ in the two types of rafts known to exist in RBC. One type contains primarily stomatin and the flotillins (flotillin1 and 2). While the palmitoylated, hydrophobic stomatin is an integral membrane protein, the flotillins are peripheral membrane proteins with hydrophobic domains capable of associating with the bilayer (Salzer et al., 2002, 2008). Microvesicles (160 nm diameter) from RBC stored for more than 20 days (Kriebardis et al., 2008) and from $\mathrm{Ca}^{2+}$ loaded RBC (Salzer et al., 2002) contain band 3, are enriched in acetylcholinesterase and in stomatin (2-fold as compared to the original membrane), but threefold depleted of flotillin 2 that remains in the residual RBC membrane (Salzer et al., 2008). The thrombogenic activity of microvesicles released 
from stored $\mathrm{RBC}$ or from $\mathrm{Ca}^{2+}$ and ionophore treated $\mathrm{RBC}$ is comparable (Salzer et al., 2008). Microvesicles from long stored RBC contain heavily aggregated hemoglobin, band 3 aggregates and increasing amounts of autologous IgG (Kriebardis et al., 2008), while the residual RBC reveal a decrease in band 3 content, but yet a substantial increase in bound IgG (Kriebardis et al., 2007). Both types of microvesicles also contain small amounts of synexin and sorcin. The two peripheral membrane proteins, synexin and sorcin are predominantly associated with the second type of lipid raft in RBC and become the major proteins in the $\mathrm{Ca}^{2+}$-induced nanovesicles (60 nm diameter) (Salzer et al., 2002). Nanovesicles lack band 3, contain little stomatin, but are highly enriched in the two peripheral proteins synexin and sorcin, two proteins that were not known to exist in RBC (Salzer et al., 2002). Synexin is an annexin-like protein and binds in a $\mathrm{Ca}^{2+}$ dependent manner to sorcin and the cytoplasmic side of the budding membrane of nanovesicles. In other cells the two proteins play important roles in fusion of lamellar bodies (Sen et al., 1997).

The sequence of events in microvesicle and nanovesicle formation and release illustrates that cellular aging as evident from increasing amounts of oxidized hemoglobin, aggregated band 3 protein and surface-bound IgG appears to induce an entrapment of these irreversible endproducts in lipid raft-containing microvesicles that are rapidly cleared. The rapid clearance of these microvesicles occurs most likely by Kupfer cells and other macrophages via recognition of exposed PS, as established in an animal model using rats (Willekens et al., 2005). The selective release of vesicles containing aggregated band 3 with bound naturally occurring antibodies evidently prevents a premature recognition of the aging $\mathrm{RBC}$ by phagocytes.

\section{NATURALLY OCCURRING ANTI-BAND 3 ANTIBODIES AND COMPLEMENT IN CLEARANCE OF SENESCENT HUMAN RBC}

When Kay published her first paper on the "mechanism of removal of senescent cells by human macrophages" in 1975 it was the first contribution that addressed the selective clearance of in vivo aged human RBC (Kay, 1975). Senescent but not young $\mathrm{RBC}$, as obtained by density separation, are phagocytosed by macrophages, while phagocytosis of in vitro aged RBC requires opsonization with autologous IgG. IgG eluted from senescent RBC induces phagocytosis of in vitro stored young RBC (Kay, 1978). These findings demonstrated that "opsonization of aging RBC by autologous IgG" represents the effect of "beneficial autoantibodies," of "physiologic autoantibodies" that were also called natural antibodies or naturally occurring (auto)antibodies (NAbs). NAbs with beneficial roles had already been observed in 1942 (Kidd and Friedewald, 1942), but went almost unnoticed during the rapid development of classical immunology in the 60 and $70 \mathrm{~s}$. This situation changed in the early $80 \mathrm{~s}$ with the description of NAbs against nine common human antigens (Guilbert et al., 1982) and the availability of the immunoblotting technique to visualize binding of whole IgG to individual membrane proteins (Towbin et al., 1979) and to embark on the affinity purification of NAbs to RBC membrane proteins like spectrin (Lutz and Wipf, 1982) and band 3 (Lutz et al., 1984).

In trying to identify the antigen exposed on aged RBC Kay carried out affinity purification of RBC proteins on immobilized IgG from senescent RBC and reported that this IgG NAb binds to a $62 \mathrm{kDa}$ protein of old RBC (Kay, 1981). At the same time Lutz had evidence for band 3 oligomers to represent the antigen to which autologous IgG binds to (Lutz, 1981). The immune precipitate obtained with second antibody from detergent extracts of ${ }^{125} \mathrm{I}$ iodinated RBC contained material at 100 and $200 \mathrm{kDa}$ and shared iodinated peptide maps with that of band 3 protein. Analogous precipitates from chymotrypsin-treated $\mathrm{RBC}$ yielded primarily a labeled $65 \mathrm{kDa}$ fragment, implying that the intact antigen was band 3 (the two chymotryptic fragments of band 3 were ascribed the MW of 65 and $38 \mathrm{kDa}$ to the carbohydrate-containing fragment, later with sequence data available these fragments were named 55 and $35 \mathrm{kDa}$ fragment). Lutz and coworkers could establish that the antigenic site preexists in band 3 protein, but becomes accessible for NAb binding upon band 3 clusterization e.g., on spectrin-free vesicles in which band 3 is laterally mobile. This overview was concluded by suggesting that also in Kay's experiments the RBC-specific NAb may have bound to band 3/band 3 aggregates, but ended up in a $62 \mathrm{kDa}$ fragment because of proteolysis (Lutz, 1981). The above mentioned data could not be published in a prestigious journal, because the existence of antiband 3 NAbs had not yet been proven, though immunoblots with whole IgG revealed not only binding to both spectrin band 1 and 2 but also to band 3 (Lutz and Wipf, 1982). Eventually the entire information was published in pieces: Binding of autologous IgG was 14 times higher to spectrin-free vesicles than to ATP-maintaining RBC (Müller and Lutz, 1983), implying that NAb binding increases with oligomerization of integral membrane proteins. A detailed study of the glycoprotein topology on human RBC after an extensive aminogroup supplementation further showed that the $10^{6}$ band 3 molecules exist either as monomers or non-crosslinkable dimers of which the crosslinkable portion is minute, but increases at a confidence level of 0.06 by $0.4 \%$ from young to senescent cells (Schweizer et al., 1982). By leucocyte-depletion of RBC, by inhibiting proteases with phenylmethyl sulfonyl chloride (PMSF), by surface- ${ }^{125} \mathrm{I}$ iodinating young and old RBC, by extraction with Triton and addition of a second antibody it was demonstrated that preexisting immune complexes contained band 3 monomers and oligomers in samples from old but not young RBC (Lutz and Stringaro-Wipf, 1983). Furthermore, preincubation of extracts from young $\mathrm{RBC}$ with autologous IgG resulted in immunoprecipitation of band 3, again suggesting the preexistence of antigenic sites in young RBC. Finally, anti-band 3 NAbs were purified from IgG of individuals and pooled IgG (Sandoglobulin) and characterized (Lutz et al., 1984). The antigenic site of anti-band 3 NAbs is located within the $65 \mathrm{kDa}$, but not the $38 \mathrm{kDa}$ chymotryptic fragment of band 3 and antigenic band 3 protein is equally present on young and old RBC, implying that exposure requires an altered accessibility rather than an enzymatic generation of antigenic sites as suggested by Kay (Kay and Goodman, 1984). Indeed binding of purified anti-band 3 NAbs was about 10 times higher to band 3 oligomers than to monomers (Lutz et al., 1984).

In 1983 Kay followed the initial observation of Lutz et al. and reported that the senescent cell antigen is immunologically related to band 3, because not only the $62 \mathrm{kDa}$ protein, but also intact band 3 inhibited phagocytosis of RBC incubated with IgG 
eluted from senescent RBC (Kay et al., 1983). In contrast to earlier work from her group, RBC studied in this paper were leucocytedepleted and proteases inhibited in extracts. Correspondingly the stained band pattern of RBC ghosts did not reveal the $62 \mathrm{kDa}$ fragment [for comparison see reference Kay (1981)]. The antisenescent cell IgG was said to bind to both chymotryptic fragments from band 3, though the blot showed almost exclusive binding to the larger chymotryptic fragment (Kay, 1984). While this disagreement on anti-band 3 specificity continued (Kay et al., 1988; Kay, 1992), others built on the findings of Lutz et al. and extended their own studies on cell age dependent hemichrome binding to band 3 protein (Waugh and Low, 1985) by asking whether the clustering of band 3 , which is induced by denatured hemoglobin might also promote binding of autologous IgG (Low et al., 1985). Indeed, oxidative damage induced by a phenylhydrazine treatment of RBC, known to result in hemichromes, greatly stimulated binding of autologous IgG and IgG binding colocalized with band 3 protein (Low et al., 1985). Sorette and Clark raised their doubts on the treatment with phenylhydrazine to simulate cell aging and showed that the highest IgG binding was to RBC with membrane lesions (Sorette and Clark, 1991). Drenckhahn a former collaborator of Low continued their joint studies and demonstrated that RBC of patients with unstable, oxidation-sensitive forms of hemoglobin (Heinz body anemia, hemoglobin Köln, and sickle cell anemia) revealed a co-clustering of denatured hemoglobin, of band 3 protein and of RBC-bound immunoglobulins, without having to pretreat RBC with an exogenous oxidizing agent (Schlüter and Drenckhahn, 1986). Low's group then isolated the densest human RBC and showed it contained 6 times more membrane bound hemichromes and 10 times more surface-bound autologous IgG than other RBC fractions of lower density (Kannan et al., 1991). They even managed to enrich the microscopic aggregates comprised of hemichromes, band 3 and spectrin, constituting $0.09 \%$ of the membrane protein, but carrying $55 \%$ of the total cell-bound IgG.

On a meeting in Israel Arese and Lutz got to know each other and decided to collaborate by using the phagocytosis assay with diamide-treated human RBC developed in Arese's lab (Bussolino et al., 1987) to investigate the functional properties of purified anti-band 3 NAbs. Anti-band 3 NAbs purified from pooled human IgG (Sandoglobulin) bound to SS group-containing band 3 oligomers and stimulated phagocytosis of diamide-treated RBC maximally at 10-20 $\mu \mathrm{g} / \mathrm{ml}$ (Lutz et al., 1987). Largely unexpected was that efficient phagocytosis required $\mathrm{C} 3 \mathrm{~b}$ deposition, unless anti-band 3 NAbs were added at 20-100 times the physiological concentration. $\mathrm{C} 3 \mathrm{~b}$ binding to diamide-treated $\mathrm{RBC}$ was about two orders of magnitude higher than that of anti-band 3 NAbs and even occurred under alternative complement pathway conditions (Lutz et al., 1987). Likewise, senescent RBC having a five-fold lower creatine content than young RBC not only contained significantly more IgG, but also SDS-resistant complexes comprised of IgG and $\mathrm{C} 3 \mathrm{~b}$ as verified by immunoblotting with anti-IgG and anti-C3c (Lutz et al., 1988). Then, by quantifying the binding of labeled anti-band 3 NAbs to C3 it became obvious that anti-band 3 NAbs have a unique affinity for C3, while anti-spectrin NAbs not (Lutz et al., 1989). The weak affinity for $\mathrm{C} 3\left(2-3 \times 10^{5} \mathrm{l} / \mathrm{mol}\right)$ at a site independent of the antigen binding domain is about 100 times higher than that of whole IgG, known to have a weak affinity for C3 (Lutz et al., 1993b). This affinity for $\mathrm{C} 3$ is responsible for the preferential formation of C3b-IgG and C3 $\mathrm{b}_{2}$-IgG complexes during complement activation (Lutz et al., 1993c). Years later Jelezarova et al. verified that all such complexes contain dimeric C3b (C3b $\left.b_{2}-\mathrm{IgG}\right)$, esterbonded to one heavy chain of IgG (Jelezarova et al., 2003). It is the dimeric $\mathrm{C} 3 \mathrm{~b}$ within these complexes that renders them efficient activators of the alternative complement pathway. Thus, the ability of certain low affinity NAbs, like anti-band 3, to form such complexes during complement activation renders them far more efficient opsonins than judged from the number of bound antibody. Frank and collaborators had earlier found that certain induced IgG antibodies to bacteria also formed covalent complexes with $\mathrm{C} 3 \mathrm{~b}$ (C3b-IgG), which rendered these IgG molecules 3-4 fold more effective in stimulating complement deposition (Joiner et al., 1985).

To clarify the homeostatic role of purified anti-band 3 NAbs the survival of untreated and diamide-treated RBC was investigated in guinea pigs. In normal, but not in C3-deficient guinea pigs human anti-band $3 \mathrm{NAb}$ binding significantly accelerated the clearance of diamide-treated guinea pig RBC (Giger et al., 1995). Likewise, a pretreatment of the animals with $200 \mu \mathrm{g}$ of human band 3 protein slowed down the clearance of diamidetreated guinea pig RBC to the extent observed without anti-band 3 NAbs. In support of the role of complement Turrini et al. used either $\mathrm{ZnCl}_{2}$, acridine orange or melittin to cluster integral membrane proteins and determined binding of autologous IgG, complement $\mathrm{C} 3 \mathrm{c}$ and quantified phagocytosis. The authors could confirm and extend the observations from the group of Lutz in so far as the clustering agent was only effective upon subsequent crosslinking of aggregated band 3 protein and only then induced binding of autologous IgG, deposition of C3c and phagocytosis (Turrini et al., 1991). IgG eluted following disaggregation of band 3 oligomers bound almost exclusively to band 3 , its dimer and oligomers (Turrini et al., 1993). Disulfide-crosslinked band 3 dimers are indeed the minimal band 3 aggregates with enhanced affinity for anti-band 3 NAbs (Turrini et al., 1994). Similar conclusions were drawn by Beppu et al., using three different approaches to oxidize human RBC. All pretreatments increased binding of autologous IgG as well as of purified anti-band 3 NAbs and binding was inhibited by purified band 3 protein or by restoration of the protein $\mathrm{SH}$ groups (Beppu et al., 1990).

Oxidation or a treatment with a clustering agent and cross-linking of the generated clusters evidently simulates the prerequisites for clearance of RBC, but does not explain how band 3 clusters are formed during in vivo aging. Several authors have focused on the potential role of superoxide and NO, known to form peroxynitrite that induces lipid peroxidation and oxidizes hemoglobin to methemoglobin (Matarrese et al., 2005). Oxidative damage by peroxynitrite induces tyrosine phosphorylation of band 3 protein by several orders of magnitude and this phosphorylation enables the dissociation of band 3 from the spectrin-actin skeleton by lowering its affinity for ankyrin, whereby its cross-linkability and in plane diffusion are elevated (Ferru et al., 2011). Despite peroxynitrite can induce the 
oxidation of hemoglobin, can provide the prerequisite for band 3 protein oligomerization and can enable exoplasmic PS exposure, all these alterations are reversed by reactivation of glycolysis (Pietraforte et al., 2007). This implies that damage is minimal in aging RBC as long as ATP levels are maintained. Hence, peroxynitrite may contribute to oxidative damage in microvesicles, but not in aging RBC that maintain their ATP concentration at a high level and do not expose PS exoplasmically. An elegant recent report has finally brought the answer. Arashiki et al. have shown that efficient binding of methemoglobin to band 3 protein, requires a preceding peroxidation of the cytoplasmic portion of band 3 protein (Arashiki et al., 2013). Peroxidation of the cytoplasmic portion of band 3 protein results in carbonylation of this domain and this in turn enhances methemoglobin binding 5-7 fold. Bound methemoglobin then induces a conformational change which displaces ankyrin and gives rise to band 3 cluster formation.

\section{ANTI-BAND 3 NAbs AND INDUCED ANTI-LACTOFERRIN ANTIBODIES}

Anti-band 3 NAbs, as isolated from plasma of healthy blood donors with blood group $\mathrm{O}$ or from Sandoglobulin bound to band 3 and exclusively to the $68 / 55 \mathrm{kDa}$ chymotryptic fragment of band 3, but not to the carbohydrate-containing, $38 / 35 \mathrm{kDa}$ fragment (Lutz et al., 1984). Eight years later Beppu reported that their anti-band 3 NAbs bind to the sialylated $\mathrm{N}$-acetyllactosaminyl carbohydrate group localized within the $38 \mathrm{kDa}$ fragment of band 3 (Beppu et al., 1992; Ando et al., 1994). Lutz et al. reinvestigated the specificity of anti-band 3 NAbs purified from pooled human IgG as found in Sandoglobulin. Anti-band 3 NAbs as prepared originally bound to band 3 and weakly to the cytoskeletal proteins band 4.2, 5 and spectrin. In the reinvestigation anti-band 3 NAbs were further purified by absorption on heat aggregated human IgG to deplete of antiidiotypes. Anti-band 3 NAbs obtained in this manner bound on blots exclusively to band 3 and to the $55 \mathrm{kDa}$ chymotryptic fragment of band 3 , but not the $38 \mathrm{kDa}$ chymotryptic fragment of band 3 (Lutz et al., 1993a). A detailed analysis further showed that binding of anti-band 3 NAbs to blotted band 3 protein from $\mathrm{RBC}$ membranes was neither inhibited by pretreating $\mathrm{RBC}$ with neuraminidase nor endo- $\beta$-galactosidase. In addition, its binding to band 3 and to the $55 \mathrm{kDa}$ fragment of band 3 was not inhibited at all by $10 \mu \mathrm{g} / \mathrm{ml}$ lactoferrin (Lutz et al., 1993a). This was in complete contrast to the properties of Beppu's "anti-band 3 antibodies," for which these authors showed an $80 \%$ inhibition of binding to oxidatively stressed RBC by $10 \mu \mathrm{g} / \mathrm{ml}$ lactoferrin (Beppu et al., 1992). The consequence was that many investigators in the RBC field considered the specificity of anti-band 3 NAbs as unresolved, as remaining controversial.

The second round of studying anti-band 3 specificity confirmed the initial characterization of anti-band $3 \mathrm{NAb}$ preparations of Lutz and suggested that Beppu's group must have used a different type of starting material that upon purification on immobilized band 3 protein yielded anti-N-acetyllactosaminylspecific IgG and anti-band 3 NAbs. This possibility was later rendered even more likely, when Ando et al. (1996) showed that $70 \%$ of their anti-band 3 antibodies bound to lactoferrin and
$30 \%$ to a non-glycosylated portion of band 3 protein. The source of their starting material was ill defined: was serum from persons with blood group $\mathrm{AB}$, (Beppu et al., 1992), blood group B (Beppu et al., 1990), normal adults (Fujino et al., 2000) and was further treated for $30 \mathrm{~min}$ at $56^{\circ} \mathrm{C}$, at least in the first paper (Beppu et al., 1990). Nevertheless, none of these starting materials could explain the copurification of the two types of antibodies on band 3 protein. Years later, with additional clinical information available, Lutz came up with the suggestion that Beppu's group must have used serum/plasma from patients with one of the many autoimmune diseases that are characterized by anti-neutrophil cytoplasmic antibodies (ANCA) (Lutz, 2012). IgG anti-lactoferrin is one of the induced autoantibodies in patients with rheumatoid arthritis (Kida et al., 2011), systemic lupus erythematosus (Caccavo et al., 2005), ulcerative colitis (Peen et al., 1993; Teegen et al., 2009), cholangitis (Muratori et al., 2001), and many other chronic diseases. In contrast to this, healthy humans have no IgG anti-lactoferrin at all, as verified by ELISA on 34 (Caccavo et al., 2005) and 36 (Chikazawa et al., 2000) serum samples and by immunoblotting (Nässberger et al., 1994). Thus, the purified IgG antibody preparation from Beppu's group should not have been named "anti-band 3 Nab." Their preparation is evidently a mixture of NAbs with an induced autoantibody.

On the other hand, the functional properties that Beppu's group has described for this mixture of anti-band 3 and antilactoferrin reveal an unexpected implication, namely that not only anti-band 3 NAbs, but also anti-lactoferrin antibodies bind to oxidatively stressed and aging $\mathrm{RBC}$ and together increase opsonization with IgG and complement (Beppu et al., 1996; Ando et al., 1997). The consequence is that patients with induced IgG anti-lactoferrin antibodies may suffer from anemia as was found for example in 6 SLE patients having no other ANCA type antibody, but anti-lactoferrin (Manolova, 2003). In other studies anemia accompanying the presence of anti-lactoferrin antibodies was characterized on the basis of diminished hemoglobin concentrations, elevated erythrocyte sedimentation rates (ESR) and/or a higher red blood cell distribution width (RDW) as for example in rheumatoid arthritis and SLE (Chikazawa et al., 2000; Caccavo et al., 2005) and inflammatory bowel diseases (Song et al., 2012). In these anemias of chronic disease (Weiss and Goodnough, 2005) erythropoiesis is not increased in proportion to the enhanced RBC clearance. No one in the medical field has considered the possibility that extra opsonization of aging RBC by IgG antilactoferrin may result in accelerated removal of normal, aging $\mathrm{RBC}$ and eventually in anemia. The presence of anti-lactoferrin in IgG eluates from ageing RBC of such patients would provide the proof.

The anemia developing from the enhanced clearance of aging RBC by bound anti-band 3 and anti-lactoferrin could be cured by treatment with human or bovine lactoferrin per os. Lactoferrin would complex anti-lactoferrin and thereby prevent it from binding to the $38 \mathrm{kDa}$ fragment of band 3 on aging RBC. Indeed, treatment with lactoferrin appears to stop anemia of chronic disease: for example RBC from New Zealand Black mice, constitutively suffering from an autoimmune type RBC clearance, had fewer numbers of Coombs-positive RBC upon treatment with bovine lactoferrin (Zimecki et al., 1995). In humans $200 \mathrm{mg} /$ day 
of orally applied lactoferrin in combination with erythropoietin normalized the hemoglobin concentration in 75 cancer patients with anemia of chronic disease (Macciò et al., 2010). In fact, lactoferrin was as effective as injection of $125 \mathrm{mg}$ ferric gluconate per week along with erythropoietin, but reduced serum ferritin significantly. Lactoferrin was also effective in treating pregnant women with iron deficiency anemia: Oral administration of lactoferrin ( $100 \mathrm{mg} /$ twice a day for 30 days), that was iron-saturated to $30 \%$, increased the total serum iron and hemoglobin concentrations to a greater extent than administration of ferrous sulphate (156 mg/day) in 60 anemic women (Paesano et al., 2009, 2010). These authors also found that the lactoferrin treatment lowered the serum concentration of IL6 from 32 to $12 \mathrm{pg} / \mathrm{ml}$ and therefore think that this mitigated inhibition of ferroportin 1 on macrophages and thereby enhanced iron export to blood for efficient erythropoiesis (Paesano et al., 2010). These thoughts call for clinical trials in which patients with anemia of chronic disease will be studied for IgG anti-lactoferrin antibodies in their serum and if positive, will eventually be treated with oral lactoferrin.

\section{OTHER CLEARANCE MECHANISMS}

All the above mentioned findings differ completely from the old idea that desialylation is the trigger for removal of senescent RBC (Henrich and Aminoff, 1983; Bratosin et al., 1995). Fudenberg and coworkers addressed this question from a different viewpoint and asked whether heat-eluted IgG from senescent RBC has the same specificity as anti-Thomson-Friedenreich antibodies (anti-T), that are generated against neuraminidase-treated RBC glycoproteins. A pretreatment of RBC with anti-T antibodies did not alter the binding of heat-eluted IgG (Khansari et al., 1983). Thus, the two binding sites differ from each other and IgG from senescent RBC do not bind at all to desialylated sites.

"Eryptosis or suicidal erythrocyte death" as portrayed by Lang et al. (2008) should not be considered a senescence-like mechanism in healthy humans. Eryptosis is induced by several types of stresses, in particular by entry of $\mathrm{Ca}^{2+}$ ions followed by the loss of potassium ions, cell shrinkage, exposure of exoplasmic phosphatidylserine, and recognition by phagocytes. Eryptosis is not a senescence variant, because RBC in vivo aged for 110126 days do not expose PS as illustrated in chapter 2 (Franco et al., 2013). In fact Lang and coworkers have recently studied eryptosis on young and old human RBC and confirmed that PS exposure was similarly negligible in young and old RBC, but increased upon induction of eryptosis more so in old than young RBC (Ghashghaeinia et al., 2012). Eryptosis may contribute to accelerated RBC clearance in a number of systemic diseases like hemolytic uremic syndrome and in sepsis (Lang et al., 2008).

There were reports on yet another mechanism of how senescent RBC may be tagged. Galili and coworkers described anti$\alpha \mathrm{Gal}$ antibodies as representing natural antibodies existing in the plasma of all humans at high concentrations of up to $1 \%$ of total IgG (Galili et al., 1986). Most of bound IgG could be stripped off from old RBC by galactose and RBC stripped from bound IgG were phagocytosed upon addition of anti- $\alpha \mathrm{Gal}$. Clark and collaborators reinvestigated the role of anti- $\alpha \mathrm{Gal}$ and found that in eluates from senescent RBC 9-39\% of total IgG had anti- $\alpha$ Gal and $5-18 \%$ anti-band 3 specificity (Clark and
Sorette, 1991). Considering the fact that human plasma contains $100-1000$ times more anti- $\alpha$ Gal than anti-band 3 NAbs, the retention of anti- $\alpha \mathrm{Gal}$ antibodies was due to incomplete removal by washing. A year later Galili and coworkers no longer reported that anti- $\alpha$ Gal could be involved in removal of aged human RBC, because human cells lack the $\alpha 1,3 \mathrm{Gal}$ structure, while this epitope has been found on surface glycoconjugates of other mammalian cells and on many bacterial surfaces (Hamadeh et al., 1992). In fact, anti- $\alpha \mathrm{Gal}$ is most likely an induced antibody rather than a NAb.

After Lutz had isolated and characterized anti-spectrin NAbs from human IgG, Wiener et al. found significantly increased plasma concentrations of anti-spectrin NAbs in splenectomized patients with $\beta$-thalassemia major and in patients with sickle cell anemia (Wiener et al., 1986). Surprisingly, eluates from patients' RBC also revealed anti-spectrin NAbs. The authors concluded that binding of these NAbs to intact RBC may either be due to abnormally exposed spectrin or because of a crossreaction. Irrespective of the reason for bound anti-spectrin NAbs, the increased number of bound IgG as such most likely had a stimulating effect on the clearance of these cells. Berti and collaborators later reported analogous findings for RBC from rats and hypertransfused rats, incubated with induced rat antispectrin antibodies (Giuliani et al., 2000). In trying to understand the phenomenon the group of Lutz reported that an exoplasmic cross-linking of band 3 protein on human RBC not only enhanced binding of anti-band 3 , but also that of purified ${ }^{125} \mathrm{I}$ iodinated anti-spectrin NAbs $7-10$ fold at $0^{\circ} \mathrm{C}$ in the presence of nearly physiological IgG and HSA concentrations (Hornig and Lutz, 2000). Binding of anti-spectrin NAbs was not competed by anti-band 3 NAbs and bound anti-spectrin NAbs even stimulated binding of anti-band 3 NAbs by $30 \%$. While anti-spectrin NAbs bound at physiologic tonicity to band 3 or an associated protein by virtue of their inherent polyreactivity (Hornig and Lutz, 2000), their interaction with other components is increased at low ionic strength (Heegaard, 1993). The role of anti-spectrin NAbs is most likely to opsonize ghosts, generated from hemolysing RBC in circulation, as has been studied in detail (Salhany et al., 2001).

RBC contain a surface protein that protects RBC from being phagocytosed, CD47 (integrin-associated protein). When RBC in circulation bump into macrophages, CD47 actively prevents engulfment by binding to SIRP $\alpha$ on macrophages and this interaction provides a "do not eat me signal" [for a review see reference Matozaki et al. (2009)]. Recently, Burger et al. suggested that CD47 may act like a molecular switch from suppression to promotion of phagocytosis, when it may facilitate recognition and phagocytosis of aged RBC by macrophages (Burger et al., 2012). The authors think that RBC aging induces a conformational change in CD47 whereby it binds thrombospondin-1 and then interacts with $\operatorname{SIRP} \alpha$ and induces phagocytosis of aged RBC. The evidence is weak, because the required concentration of the thrombospondin-1 peptide exceeded the thrombospondin-1 concentration in plasma by $10^{3}-10^{4}$ (Lutz, 2013) and the phenomena had been studied on RBC that (a) were not actively leucocyte-depleted and (b) were oxidatively damaged by $\mathrm{CuSO}_{4}$ and ascorbic acid rather than in vivo aged. 


\section{CONCLUDING REMARKS}

Covered in this review are the mechanisms of senescence of $\mathrm{RBC}$ in healthy humans. These mechanisms may differ for RBC of patients with hereditary anemias or polycytemia and those observed in RBC during storage. In these cases calcium uptake, PS exposure and abnormal alterations in cell volume, membrane architecture, as well as redox balance may play a much more important role. The presentation of senescent RBC from healthy humans to phagocytes is mediated by complement, but initiated by naturally occurring anti-band 3 antibodies that bind to aggregated band 3 protein. A very similar, additive effect may have induced anti-lactoferrin antibodies in autoimmune diseases characterized by ANCA. The induced anti-lactoferrin antibodies bind to the carbohydrate portion of the band 3 protein and appear to accelerate clearance of otherwise normal senescent RBC and may induce anemia.

\section{ACKNOWLEDGMENTS}

This review was supported by the CoMMiTMenT project funded by the European Community's Seventh Framework Programme (FP7/2007-2013) under Grant Agreement No. 602121.

\section{REFERENCES}

Abugo, O. O., and Rifkind, J. M. (1994). Oxidation of hemoglobin and the enhancement produced by nitroblue tetrazolium. J. Biol. Chem. 269, 24845-24853.

Allan, D., and Michell, R. H. (1977). Calcium ion-dependent diacylglycerol accumulation in erythrocytes is associated with microvesiculation but not with efflux of potassium ions. Biochem. J. 166, 495-499.

Ando, K., Kikugawa, K., and Beppu, M. (1994). Involvement of sialylated poly-Nacetyllactosaminyl sugar chains of band 3 glycoprotein on senescent erythrocytes in anti-band 3 autoantibody binding. J. Biol. Chem. 269, 19394-19398.

Ando, K., Kikugawa, K., and Beppu, M. (1996). Binding of anti-band 3 autoantibody to sialylated poly-N- acetyllactosaminyl sugar chains of band 3 glycoprotein on polyvinylidene difluoride membrane and sepharose gel: further evidence for anti-band 3 autoantibody binding to the sugar chains of oxidized and senescent erythrocytes. J. Biochem. 119, 639-647. doi: 10.1093/oxfordjournals.jbchem.a021290

Ando, K., Kikugawa, K., and Beppu, M. (1997). Induction of band 3 aggregation in erythrocytes results in anti-band 3 autoantibody binding to the carbohydrate epitopes of band 3. Arch. Biochem. Biophys. 339, 250-257. doi: 10.1006/abbi.1996.9831

Antonelou, M. H., Tzounakas, V. L., Velentzas, A. D., Stamoulis, K. E., Kriebardis, A. G., and Papassideri, I. S. (2012). Effects of pre-storage leukoreduction on stored red blood cells signaling: a time-course evaluation from shape to proteome. J. Proteomics 76 Spec No., 220-238. doi: 10.1016/j.jprot.2012.06.032

Arashiki, N., Kimata, N., Manno, S., Mohandas, N., and Takakuwa, Y. (2013). Membrane peroxidation and methemoglobin formation are both necessary for band 3 clustering: mechanistic insights into human erythrocyte senescence. Biochemistry 52, 5760-5769. doi: 10.1021/bi400405p

Bartkowiak, A., Grzelinska, E., and Bartosz, G. (1983). Aging of the erythrocyteXVII. Changes in the properties of superoxide dismutase. Int. J. Biochem. 15, 763-765. doi: 10.1016/0020-711X(83)90207-0

Bartosz, G. (1980). Aging of the erythrocyte. VII. On the possible causes of inactivation of red cell enzymes. Mech. Ageing Dev. 13, 379-385. doi: 10.1016/00476374(80)90079-2

Bartosz, G. (1981). Aging of the erythrocyte. VIII. Sensitivity to oxidant factors. Acta Biol. Med. Ger. 40, 985-989.

Bartosz, G., Tannert, C., Fried, R., and Leyko, W. (1978). Superoxide dismutase activity decreases during erythrocyte aging. Experientia 34, 1464. doi: 10.1007/BF01932355

Beppu, M., Eda, S., Fujimaki, M., Hishiyama, E., and Kikugawa, K. (1996). Recognition of poly-N-acetyllactosaminyl saccharide chains on iron-oxidized erythrocytes by human monocytic leukemia cell line THP-1 differentiated into macrophages. Biol. Pharm. Bull. 19, 188-194. doi: 10.1248/bpb.19.188
Beppu, M., Mizukami, A., Ando, K., and Kikugawa, K. (1992). Antigenic determinants of senescent antigen of human erythrocytes are located in sialylated carbohydrate chains of band-3 glycoprotein. J. Biol. Chem. 267, 14691-14696.

Beppu, M., Mizukami, A., Nagoya, M., and Kikugawa, K. (1990). Binding of antiband 3 autoantibody to oxidatively damaged erythrocytes. J. Biol. Chem. 265, 3226-3233.

Beutler, E., West, C., and Blume, K.-G. (1976). The removal of leukocytes and platelets from whole blood. J. Lab. Clin. Med. 88, 328-333.

Bevers, E. M., Wiedmer, T., Comfurius, P., Shattil, S. J., Weiss, H. J., Zwaal, R. F. A., et al. (1992). Defective $\mathrm{Ca}^{+}{ }^{+}$-Induced microvesiculation and deficient expression of procoagulant activity in erythrocytes from a patient with a bleeding disorder-a study of the red blood cells of Scott syndrome. Blood 79, 380-388.

Blostein, R., and Grafova, E. (1987). Factors affecting transport changes associated with reticulocyte maturation. Biomed. Biochim. Acta 46, S172-S176.

Bobrowska-Hagerstrand, M., Wrobel, A., Rychlik, B., Bartosz, G., Soderstrom, T., Shirataki, Y., et al. (2001). Monitoring of MRP-like activity in human erythrocytes: inhibitory effect of isoflavones. Blood Cells Mol. Dis. 27, 894-900. doi: 10.1006/bcmd.2001.0459

Bookchin, R. M., Etzion, Z., Sorette, M., Mohandas, N., Skepper, J. N., and Lew, V. L. (2000). Identification and characterization of a newly recognized population of high-Na ${ }^{+}$, low- $\mathrm{K}^{+}$, low-density sickle and normal red cells. Proc. Natl. Acad. Sci. U.S.A. 97, 8045-8050. doi: 10.1073/pnas.130198797

Bordin, L., Ion-Popa, F., Brunati, A. M., Clari, G., and Low, P. S. (2005). Effectorinduced Syk-mediated phosphorylation in human erythrocytes. Biochim. Biophys. Acta 1745, 20-28. doi: 10.1016/j.bbamcr.2004.12.010

Borges-Alvarez, M., Benavente, F., Barbosa, J., and Sanz-Nebot, V. (2012). Separation and characterization of superoxide dismutase 1 (SOD-1) from human erythrocytes by capillary electrophoresis time-of-flight mass spectrometry. Electrophoresis 33, 2561-2569. doi: 10.1002/elps.201100672

Bosch, F. H., Werre, J. M., Roerdinkholderstoelwinder, B., Huls, T. H., Willekens, F. L. A., and Halie, M. R. (1992). Characteristics of red blood cell populations fractionated with a combination of counterflow centrifugation and Percoll separation. Blood 79, 254-260.

Bosman, G. J., Cluitmans, J. C., Groenen, Y. A., Werre, J. M., Willekens, F. L., and Novotny, V. M. (2011). Susceptibility to hyperosmotic stress-induced phosphatidylserine exposure increases during red blood cell storage. Transfusion 51, 1072-1078. doi: 10.1111/j.1537-2995.2010.02929.x

Bosman, G. J., and Kay, M. M. (1990). Alterations of band 3 transport protein by cellular aging and disease: erythrocyte band 3 and glucose transporter share a functional relationship. Biochem. Cell Biol. 68, 1419-1427. doi: 10.1139/ o90-205

Bratosin, D., Mazurier, J., Debray, H., Lecocq, M., Boilly, B., Alonso, C., et al. (1995). Flow cytofluorimetric analysis of young and senescent human erythrocytes probed with lectins. Evidence that sialic acids control their life span. Glycoconj. J. 12, 258-267. doi: 10.1007/BF00731328

Burger, P., Hilarius-Stokman, P., de Korte, D., van den Berg, T. K., and van Bruggen, R. (2012). CD47 functions as a molecular switch for erythrocyte phagocytosis. Blood 119, 5512-5521. doi: 10.1182/blood-2011-10-386805

Bussolino, F., Turrini, F., and Arese, P. (1987). Measurement of phagocytosis utilizing ${ }^{14} \mathrm{C}$-cyanate-labelled human red cells and monocytes. Br. J. Haematol. 66, 271-274. doi: 10.1111/j.1365-2141.1987.tb01311.x

Caccavo, D., Rigon, A., Picardi, A., Galluzzo, S., Vadacca, M., Ferri, G. M., et al. (2005). Anti-lactoferrin antibodies in systemic lupus erythematosus: isotypes and clinical correlates. Clin. Rheumatol. 24, 381-387. doi: 10.1007/s10067-0041040-2

Canessa, M., Fabry, M. E., Blumenfeld, N., and Nagel, R. L. (1987). Volumestimulated, $\mathrm{Cl}^{-}$-dependent $\mathrm{K}^{+}$efflux is highly expressed in young human red cells containing normal hemoglobin or HbS. J. Membr. Biol. 97, 97-105. doi: 10.1007/BF01869416

Cardo, L. J., Wilder, D., and Salata, J. (2008). Neutrophil priming, caused by cell membranes and microvesicles in packed red blood cell units, is abrogated by leukocyte depletion at collection. Transfus. Apher. Sci. 38, 117-125. doi: 10.1016/j.transci.2008.01.004

Chikazawa, H., Nishiya, K., Matsumori, A., and Hashimoto, K. (2000). Immunoglobulin isotypes of anti-myeloperoxidase and anti-lactoferrin antibodies in patients with collagen diseases. J. Clin. Immunol. 20, 279-286. doi: 10.1023/A:1006667703202

Christian, J. A., Rebar, A. H., Boon, G. D., and Low, P. S. (1993). Senescence of canine biotinylated erythrocytes-increased autologous immunoglobulin 
binding occurs on erythrocytes aged in vivo for 104 to 110 days. Blood 82, 3469-3473.

Clark, M. R. (1985). Selected ionic and metabolic characteristics of human red cell populations separated on stractan density gradients. Prog. Clin. Biol. Res. 195, 381-388.

Clark, M. R. (1988). Senescence of red blood cells: progress and problems. Physiol. Rev. 68, 503-554.

Clark, M. R., and Sorette, M. P. (1991). Characterization of antibody that binds in vivo to normal human red blood cells. Adv. Exp. Med. Biol. 307, 357-365. doi: 10.1007/978-1-4684-5985-2_32

Cohen, N. S., Ekholm, J. E., Luthra, M. G., and Hanahan, D. J. (1976). Biochemical characterization of density-separated human erythrocytes. Biochim. Biophys. Acta 419, 229-242. doi: 10.1016/0005-2736(76)90349-7

Cohen, R. M., Franco, R. S., Khera, P. K., Smith, E. P., Lindsell, C. J., Ciraolo, P. J., et al. (2008). Red cell life span heterogeneity in hematologically normal people is sufficient to alter HbAlc. Blood 112, 4284-4291. doi: 10.1182/blood-2008-04154112

Dale, G. L., and Norenberg, S. L. (1989). Time-dependent loss of adenosine $5^{\prime}$-monophosphate deaminase activity may explain elevated adenosine $5^{\prime}$ triphosphate levels in senescent erythrocytes. Blood 74, 2157-2160.

Di Simplicio, P., Cacace, M. G., Lusini, L., Giannerini, F., Giustarini, D., and Rossi, R. (1998). Role of protein -SH groups in redox homeostasis-the erythrocyte as a model system. Arch. Biochem. Biophys. 355, 145-152. doi: 10.1006/abbi.1998.0694

Dumaswala, U. J., and Greenwalt, T. J. (1984). Human erythrocytes shed exocytic vesicles in vivo. Transfusion 24, 490-492. doi: 10.1046/j.15372995.1984.24685066807.x

Ellory, J. C., Hall, A. C., Ody, S. A., Poli de Figueiredos, C. E., Chalder, S., and Stuart, J. (1991). KCl cotransport in HbAA and HbSS red cells: activation by intracellular acidity and disappearance during maturation. Adv. Exp. Med. Biol. 307, 47-57. doi: 10.1007/978-1-4684-5985-2_5

Fehr, J., and Knob, M. (1979). Comparison of red cell creatine level and reticulocyte count in appraising the severity of hemolytic processes. Blood 53, 966-976.

Ferrali, M., Signorini, C., Ciccoli, L., Bambagioni, S., Rossi, V., Pompella, A., et al. (2000). Protection of erythrocytes against oxidative damage and autologous immunoglobulin $\mathrm{G}(\mathrm{IgG})$ binding by iron chelator fluor-benzoilpyridoxal hydrazone. Biochem. Pharmacol. 59, 1365-1373. doi: 10.1016/S00062952(00)00273-2

Ferru, E., Giger, K., Pantaleo, A., Campanella, E., Grey, J., Ritchie, K., et al. (2011). Regulation of membrane-cytoskeletal interactions by tyrosine phosphorylation of erythrocyte band 3. Blood 117, 5998-6006. doi: 10.1182/blood-2010-11317024

Fornaini, G., Magnani, M., Fazi, A., Accorsi, A., Stocchi, V., and Dacha, M. (1985). Regulatory properties of human erythrocyte hexokinase during cell ageing. Arch. Biochem. Biophys. 239, 352-358. doi: 10.1016/0003-9861(85)90698-8

Fortier, N., Snyder, L. M., Garver, F., Kiefer, C., McKenney, J., and Mohandas, N. (1988). The relationship between in vivo generated hemoglobin skeletal protein complex and increased red cell membrane rigidity. Blood 71, 1427-1431.

Franco, R. S., Lohmann, J., Silberstein, E. B., Mayfieldpratt, G., Palascak, M., Nemeth, T. A., et al. (1998). Time-dependent changes in the density and hemoglobin F content of biotin-labeled sickle cells. J. Clin. Invest. 101, 2730-2740. doi: 10.1172/JCI2484

Franco, R. S., Puchulu-Campanella, M. E., Barber, L. A., Palascak, M. B., Joiner, C. H., Low, P. S., et al. (2013). Changes in the properties of normal human red blood cells during in vivo aging. Am. J. Hematol. 88, 44-51. doi: 10.1002/ajh.23344

Fujino, T., Ando, K., Beppu, M., and Kikugawa, K. (2000). Enzymatic removal of oxidized protein aggregates from erythrocyte membranes. J. Biochem. 127, 1081-1086. doi: 10.1093/oxfordjournals.jbchem.a022701

Galili, U., Flechner, I., Knyszynski, A., Danon, D., and Rachmilewitz, E. A. (1986). The natural anti-alpha-galactosyl IgG on human normal senescent red blood cells. Br. J. Haematol. 62, 317-324. doi: 10.1111/j.1365-2141.1986.tb02935.x

George, A., Pushkaran, S., Konstantinidis, D. G., Koochaki, S., Malik, P., Mohandas, N., et al. (2013). Erythrocyte NADPH oxidase activity modulated by Rac GTPases, PKC, and plasma cytokines contributes to oxidative stress in sickle cell disease. Blood 121, 2099-2107. doi: 10.1182/blood-2012-07-441188

Ghashghaeinia, M., Cluitmans, J. C., Akel, A., Dreischer, P., Toulany, M., Koberle, M., et al. (2012). The impact of erythrocyte age on eryptosis. Br. J. Haematol. 157, 606-614. doi: 10.1111/j.1365-2141.2012.09100.x
Giger, U., Sticher, B., Naef, R., Burger, R., and Lutz, H. U. (1995). Naturally occurring human anti-band 3 autoantibodies accelerate clearance of erythrocytes in guinea pigs. Blood 85, 1920-1928.

Girasole, M., Dinarelli, S., and Boumis, G. (2012). Structural, morphological and nanomechanical characterisation of intermediate states in the ageing of erythrocytes. J. Mol. Recognit. 25, 285-291. doi: 10.1002/jmr.2170

Giuliani, A. L., Graldi, G., Veronesi, M., Previato, A., Simoni, M., Bergamini, C., et al. (2000). Binding of anti-spectrin antibodies to red blood cells and vesiculation in various in vivo and in vitro ageing conditions in the rat. Exp. Gerontol. 35, 1045-1059. doi: 10.1016/S0531-5565(00)00173-X

Gladwin, M. T., and Kim-Shapiro, D. B. (2008). The functional nitrite reductase activity of the heme-globins. Blood 112, 2636-2647. doi: 10.1182/blood-200801-115261

Gonzalez, L. J., Gibbons, E., Bailey, R. W., Fairbourn, J., Nguyen, T., Smith, S. K., et al. (2009). The influence of membrane physical properties on microvesicle release in human erythrocytes. PMC Biophys. 2, 7. doi: 10.1186/1757-5036-2-7

Greenwalt, T. J. (2006). The how and why of exocytic vesicles. Transfusion 46, 143-152. doi: 10.1111/j.1537-2995.2006.00692.x

Guilbert, B., Dighiero, G., and Avrameas, S. (1982). Naturally occurring antibodies against nine common antigens in human sera. I. Detection, isolation and characterization. J. Immunol. 128, 2779-2787.

Gutowski, K. A., Hudson, J. L., and Aminoff, D. (1991). Flow cytometric analysis of human erythrocytes 1. Probed with lectins and immunoglobulins. Exp. Gerontol. 26, 315-326. doi: 10.1016/0531-5565(91)90044-M

Hamadeh, R. M., Jarvis, G. A., Galili, U., Mandrell, R. E., Zhou, P., and Griffiss, J. M. (1992). Human natural anti-Gal IgG regulates alternative complement pathway activation on bacterial surfaces. J. Clin. Invest. 89, 1223-1235. doi: 10.1172/JCI115706

Haram, S., Carriero, D., Seaman, C., and Piomelli, S. (1991). The mechanism of decline of age-dependent enzymes in the red blood cell. Enzyme 45, 47-53.

Heegaard, N. H. H. (1993). Interactions of IgG with specific erythrocyte membrane proteins in affinity electrophoresis are highly dependent on low ionic strength conditions. Anal. Biochem. 208, 317-322. doi: 10.1006/abio.1993.1053

Henrich, C. J., and Aminoff, D. (1983). Isolation and characterization of a glycopeptide from human senescent erythrocytes. Carbohydr. Res. 120, 55-66. doi: 10.1016/0008-6215(83)88006-9

Hod, E. A., Brittenham, G. M., Billote, G. B., Francis, R. O., Ginzburg, Y. Z., Hendrickson, J. E., et al. (2011). Transfusion of human volunteers with older, stored red blood cells produces extravascular hemolysis and circulating nontransferrin-bound iron. Blood 118, 6675-6682. doi: 10.1182/blood-2011-08371849

Hornig, R., and Lutz, H. U. (2000). Band 3 protein clustering on human erythrocytes promotes binding of naturally occurring anti-band 3 and anti-spectrin antibodies. Exp. Gerontol. 35, 1025-1044. doi: 10.1016/S0531-5565(00)00126-1

Imanishi, H., Nakai, T., Abe, T., and Takino, T. (1985). Glutathione metabolism in red cell aging. Mech. Ageing Dev. 32, 57-62. doi: 10.1016/0047-6374(85)90035-1

Inaba, M., and Maede, Y. (1988). Correlation between protein 4.1a/4.1b ratio and erythrocyte life span. Biochim. Biophys. Acta 944, 256-264. doi: 10.1016/00052736(88)90439-7

Jank, H., and Salzer, U. (2011). Vesicles generated during storage of red blood cells enhance the generation of radical oxygen species in activated neutrophils. ScientificWorldJournal 11, 173-185. doi: 10.1100/tsw.2011.25

Jansen, G., Hepkema, B. G., van der Vegt, S. G., and Staal, G. E. (1986). Glycolytic activity in human red cell populations separated by a combination of density and counterflow centrifugation. Evidence for an improved separation of red cells according to age. Scand. J. Haematol. 37, 189-195. doi: 10.1111/j.16000609.1986.tb02296.x

Jelezarova, E., Luginbuehl, A., and Lutz, H. U. (2003). C3b 2 -IgG complexes retain dimeric C3 fragments at all levels of inactivation. J. Biol. Chem. 278, 51806-51812. doi: 10.1074/jbc.M304613200

Jindal, H. K., Ai, Z., Gascard, P., Horton, C., and Cohen, C. M. (1996). Specific loss of protein kinase activities in senescent erythrocytes. Blood 88, 1479-1487.

Johnson, R. M., Ho, Y. S., Yu, D. Y., Kuypers, F. A., Ravindranath, Y., and Goyette, G. W. (2010). The effects of disruption of genes for peroxiredoxin-2, glutathione peroxidase-1, and catalase on erythrocyte oxidative metabolism. Free Radic. Biol. Med. 48, 519-525. doi: 10.1016/j.freeradbiomed.2009.11.021

Joiner, K. A., Fries, L. F., Schmetz, M. A., and Frank, M. M. (1985). IgG bearing covalently bound C3b has enhanced bactericidal activity for Escherichia coli 0111. J. Exp. Med. 162, 877-889. doi: 10.1084/jem.162.3.877 
Kaestner, L., Tabellion, W., Lipp, P., and Bernhardt, I. (2004). Prostaglandin E2 activates channel-mediated calcium entry in human erythrocytes: an indication for a blood clot formation supporting process. Thromb. Haemost. 92, 1269-1272. doi: 10.1160/TH04-06-0338

Kannan, R., Yuan, J., and Low, P. S. (1991). Isolation and partial characterization of antibody-enriched and globin-enriched complexes from membranes of dense human erythrocytes. Biochem. J. 278, 57-62.

Kay, M. M. B. (1975). Mechanism of removal of senescent cells by human macrophages in situ. Proc. Natl. Acad. Sci. U.S.A. 72, 3521-3525. doi: 10.1073/pnas.72.9.3521

Kay, M. M. B. (1978). Role of physiologic autoantibody in the removal of senescent human red cells. J. Supramol. Struct. 9, 555-567. doi: 10.1002/jss.400090409

Kay, M. M. B. (1981). Isolation of the phagocytosis-inducing IgG-binding antigen on senescent somatic cells. Nature 289, 491-494. doi: 10.1038/289491a0

Kay, M. M. B. (1984). Localization of senescent cell antigen on band 3. Proc. Natl. Acad. Sci. U.S.A. 81, 5753-5757. doi: 10.1073/pnas.81.18.5753

Kay, M. M. B. (1992). Molecular mapping of human band-3 aging antigenic sites and active amino acids using synthetic peptides. J. Protein Chem. 11, 595-602. doi: 10.1007/BF01024959

Kay, M. M. B., Bosman, G. J. C. G. M., Johnson, G. J., and Beth, A. H. (1988). Band3 polymers and aggregates, and hemoglobin precipitates in red cell aging. Blood Cells 14, 275-289.

Kay, M. M. B., and Goodman, J. R. (1984). IgG antibodies do not bind to band 3 in intact erythrocytes: enzymatic treatment of cells is required for IgG binding. Biomed. Biochim. Acta 43, 841-846.

Kay, M. M. B., Goodman, S. R., Sorensen, K., Whitfield, C. F., Wong, P., Zaki, L., et al. (1983). Senescent cell antigen is immunologically related to band 3. Proc. Natl. Acad. Sci. U.S.A. 80, 1631-1635. doi: 10.1073/pnas.80.6.1631

Khansari, N., Springer, G. F., Merler, E., and Fudenberg, H. H. (1983). Mechanisms for the removal of senescent human erythrocytes from circulation: specificity of the membrane-bound immunoglobulin. Mech. Ageing Dev. 21, 49-58. doi: 10.1016/0047-6374(83)90015-5

Kida, I., Kobayashi, S., Takeuchi, K., Tsuda, H., Hashimoto, H., and Takasaki, Y. (2011). Antineutrophil cytoplasmic antibodies against myeloperoxidase, proteinase 3, elastase, cathepsin $G$ and lactoferrin in Japanese patients with rheumatoid arthritis. Mod. Rheumatol. 21, 43-50. doi: 10.1007/s10165-0100356-9

Kidd, J. G., and Friedewald, W. F. (1942). A natural antibody that reacts in vitro with a sedimentable constituent of normal tissue cells. II. Specificity of the phenomenon: general discussion. J. Exp. Med. 76, 557-578. doi: 10.1084/jem.76.6.557

Kikugawa, K., Nakauchi, K., Beppu, M., Hiramoto, K., Ando, K., and Hayakawa, M. (2000). Is nitrotyrosine generated in human erythrocytes in circulation? Biol. Pharm. Bull. 23, 379-385. doi: 10.1248/bpb.23.379

Kim, S., Park, S. Y., Kim, S. Y., Bae, D. J., Pyo, J. H., Hong, M., et al. (2012). Cross talk between engulfment receptors stabilin- 2 and integrin $\alpha \mathrm{v} \beta 5$ orchestrates engulfment of phosphatidylserine-exposed erythrocytes. Mol. Cell. Biol. 32, 2698-2708. doi: 10.1128/MCB.06743-11

Kleinbongard, P., Schulz, R., Rassaf, T., Lauer, T., Dejam, A., Jax, T., et al. (2006). Red blood cells express a functional endothelial nitric oxide synthase. Blood 107, 2943-2951. doi: 10.1182/blood-2005-10-3992

Knock, G. A., and Ward, J. P. (2011). Redox regulation of protein kinases as a modulator of vascular function. Antioxid. Redox Signal. 15, 1531-1547. doi: 10.1089/ars.2010.3614

Kriebardis, A. G., Antonelou, M. H., Stamoulis, K. E., Economou-Petersen, E., Margaritis, L. H., and Papassideri, I. S. (2007). Storage-dependent remodeling of the red blood cell membrane is associated with increased immunoglobulin G binding, lipid raft rearrangement, and caspase activation. Transfusion 47, 1212-1220. doi: 10.1111/j.1537-2995.2007.01254.x

Kriebardis, A. G., Antonelou, M. H., Stamoulis, K. E., Economou-Petersen, E., Margaritis, L. H., and Papassideri, I. S. (2008). RBC-derived vesicles during storage: ultrastructure, protein composition, oxidation, and signaling components. Transfusion 48, 1943-1953. doi: 10.1111/j.1537-2995.2008.01794.x

Lang, F., Gulbins, E., Lerche, H., Huber, S. M., Kempe, D. S., and Foller, M. (2008). Eryptosis, a window to systemic disease. Cell. Physiol. Biochem. 22, 373-380. doi: $10.1159 / 000185448$

Lee, T. H., Kim, S. U., Yu, S. L., Kim, S. H., Park, D. S., Moon, H. B., et al. (2003). Peroxiredoxin II is essential for sustaining life span of erythrocytes in mice. Blood 101, 5033-5038. doi: 10.1182/blood-2002-08-2548
Lew, V. L., and Tiffert, T. (2013). The terminal density reversal phenomenon of aging human red blood cells. Front. Physiol. 4:171. doi: 10.3389/fphys.2013.00171

Low, P. S., Waugh, S. M., Zinke, K., and Drenckhahn, D. (1985). The role of hemoglobin denaturation and band 3 clustering in red blood cell aging. Science 227, 531-533. doi: 10.1126/science. 2578228

Lucas, M., Mata, R., and Romero, A. (1988). Comparison of the active calcium extrusion, calcium buffering capacity and ATPase activity in rabbit reticulocytes and mature red cells. Biochim. Biophys. Acta 942, 65-72. doi: 10.1016/00052736(88)90275-1

Luner, S. J., Szklarek, D., Knox, R. J., Seaman, G. V. F., Josefowicz, J. Y., and Ware, B. R. (1977). Red cell charge is not a function of cell age. Nature 269, 719-721. doi: $10.1038 / 269719 \mathrm{a} 0$

Lutz, H. U. (1981). [Elimination of old erythrocytes from the circulation: exposure of a cell-age specific antigen on aging erythrocytes]. Schweiz. Med. Wochenschr. $111,1507-1517$.

Lutz, H. U. (2012). Naturally occurring anti-band 3 antibodies in clearance of senescent and oxidatively stressed human red blood cells. Transfus. Med. Hemother. 39, 321-327. doi: 10.1159/000342171

Lutz, H. U. (2013). Comment concerning the role of CD47 and signal regulatory protein alpha in regulating the clearance of aged red blood cells. Transfus. Med. Hemother. 40, 140-141. doi: 10.1159/000350507

Lutz, H. U., Bussolino, F., Flepp, R., Fasler, S., Stammler, P., Kazatchkine, M. D., et al. (1987). Naturally occurring anti-band 3 antibodies and complement together mediate phagocytosis of oxidatively stressed human red blood cells. Proc. Natl. Acad. Sci. U.S.A. 84, 7368-7372. doi: 10.1073/pnas.84.21.7368

Lutz, H. U., Fasler, S., and Stammler, P. (1989). An affinity for complement C3 as a possible reason for the potency of naturally occurring antibodies in mediating tissue homeostasis. Beitr. Infusionsther. 24, 193-199.

Lutz, H. U., Fasler, S., Stammler, P., Bussolino, F., and Arese, P. (1988). Naturally occurring anti-band 3 antibodies and complement in phagocytosis of oxidatively-stressed and in clearance of senescent red cells. Blood Cells 14, 175-195.

Lutz, H. U., and Fehr, J. (1979). Total sialic acid content of glycophorins during senescence of human red blood cells. J. Biol. Chem. 254, 11177-11180.

Lutz, H. U., Flepp, R., and Stringaro-Wipf, G. (1984). Naturally occurring autoantibodies to exoplasmic and cryptic regions of band 3 protein, the major integral membrane protein of human red blood cells. J. Immunol. 133, 2610-2618.

Lutz, H. U., Gianora, O., Nater, M., Schweizer, E., and Stammler, P. (1993a). Naturally occurring anti-band 3 antibodies bind to protein rather than to carbohydrate on band 3. J. Biol. Chem. 268, 23562-23566.

Lutz, H. U., Nater, M., and Stammler, P. (1993b). Naturally occurring anti-band 3 antibodies have a unique affinity for C3. Immunology 80, 191-196.

Lutz, H. U., Stammler, P., and Fasler, S. (1993c). Preferential formation of C3bIgG complexes in vitro and in vivo from nascent $\mathrm{C} 3 \mathrm{~b}$ and naturally occurring anti-band 3 antibodies. J. Biol. Chem. 268, 17418-17426.

Lutz, H. U., Liu, S.-C., and Palek, J. (1977). Release of spectrin-free vesicles from human erythrocytes during ATP depletion. J. Cell Biol. 73, 548-560. doi: 10.1083/jcb.73.3.548

Lutz, H. U., Stammler, P., Fasler, S., Ingold, M., and Fehr, J. (1992). Density separation of human red blood cells on self forming Percoll gradients: correlation with cell age. Biochim. Biophys. Acta 1116, 1-10. doi: 10.1016/0304-4165(92)90120-J

Lutz, H. U., and Stringaro-Wipf, G. (1983). Senescent red cell-bound IgG is attached to band 3 protein. Biomed. Biochim. Acta 42, 117-121.

Lutz, H. U., and Wipf, G. (1982). Naturally occurring autoantibodies to skeletal proteins from human red blood cells. J. Immunol. 128, 1695-1699.

Macciò, A., Madeddu, C., Gramignano, G., Mulas, C., Sanna, E., and Mantovani, G. (2010). Efficacy and safety of oral lactoferrin supplementation in combination with $\mathrm{rHuEPO}$-beta for the treatment of anemia in advanced cancer patients undergoing chemotherapy: open-label, randomized controlled study. Oncologist 15, 894-902. doi: 10.1634/theoncologist.2010-0020

Magnani, M., Piatti, E., Serafini, N., Palma, F., Dacha, M., and Fornaini, G. (1983). The age-dependent metabolic decline of the red blood cell. Mech. Ageing Dev. 22, 295-308. doi: 10.1016/0047-6374(83)90084-2

Makhro, A., Hanggi, P., Goede, S. J., Wang, J., Bruggemann, A., Gassmann, M., et al. (2013). N-methyl D-aspartate (NMDA) receptors in human erythroid precursor cells and in circulating red blood cells contribute to the intracellular calcium regulation. Am. J. Physiol. Cell Physiol. 305, C1123-C1138. doi: 10.1152/ajpcell. 00031.2013 
Makhro, A., Wang, J., Vogel, J., Boldyrev, A. A., Gassmann, M., Kaestner, L., et al. (2010). Functional NMDA receptors in rat erythrocytes. Am. J. Physiol. Cell Physiol. 298, C1315-C1325. doi: 10.1152/ajpcell. 00407.2009

Mallozzi, C., Di Stasi, M. A., and Minetti, M. (2001). Peroxynitrite-dependent activation of src tyrosine kinases lyn and hck in erythrocytes is under mechanistically different pathways of redox control. Free Radic. Biol. Med. 30, 1108-1117. doi: 10.1016/S0891-5849(01)00509-3

Mannu, F., Arese, P., Cappellini, M. D., Fiorelli, G., Cappadoro, M., Giribaldi, G., et al. (1995). Role of hemichrome binding to erythrocyte membrane in the generation of band-3 alterations in beta-thalassemia intermedia erythrocytes. Blood 86, 2014-2020.

Manolova, I. M. (2003). Anti-lactoferrin antibodies in patients with connective tissue diseases. Folia. Med. (Plovdiv). 45, 25-30.

Matarrese, P., Straface, E., Pietraforte, D., Gambardella, L., Vona, R., Maccaglia, A., et al. (2005). Peroxynitrite induces senescence and apoptosis of red blood cells through the activation of aspartyl and cysteinyl proteases. FASEB J. 19, 416-418. doi: 10.1096/fj.04-2450fje

Matozaki, T., Murata, Y., Okazawa, H., and Ohnishi, H. (2009). Functions and molecular mechanisms of the CD47-SIRPalpha signalling pathway. Trends Cell Biol. 19, 72-80. doi: 10.1016/j.tcb.2008.12.001

Mihov, D., Vogel, J., Gassmann, M., and Bogdanova, A. (2009). Erythropoietin activates nitric oxide synthase in murine erythrocytes. Am. J. Physiol. Cell Physiol. 297, C378-C388. doi: 10.1152/ajpcell.00543.2008

Minetti, M., Pietraforte, D., Straface, E., Metere, A., Matarrese, P., and Malorni, W. (2008). Red blood cells as a model to differentiate between direct and indirect oxidation pathways of peroxynitrite. Methods Enzymol. 440, 253-272. doi: 10.1016/S0076-6879(07)00816-6

Minnich, V., Smith, M. B., Brauner, M. J., and Majerus, P. W. (1971). Glutathione biosynthesis in human erythrocytes. I. Identification of the enzymes of glutathione synthesis in hemolysates. J. Clin. Invest. 50, 507-513. doi: 10.1172/JCI106519

Mohanty, J. G., Nagababu, E., Friedman, J. S., and Rifkind, J. M. (2013). SOD2 deficiency in hematopoietic cells in mice results in reduced red blood cell deformability and increased heme degradation. Exp. Hematol. 41, 316-321. doi: 10.1016/j.exphem.2012.10.017

Mueller, T., Jackson, C. W., Dockter, M. E., and Morrison, M. (1987). Membrane skeletal alterations during in vivo mouse red cell aging. Increase in the band 4.1a:4.1.b ratio. J. Clin. Invest. 79, 492-499. doi: 10.1172/ JCI112839

Müller, H., and Lutz, H. U. (1983). Binding of autologous IgG to human red blood cells before and after ATP-depletion. Selective exposure of binding sites (autoantigens) on spectrin-free vesicles. Biochim. Biophys. Acta 729, 249-257. doi: 10.1016/0005-2736(83)90491-1

Müller, H., Schmidt, U., and Lutz, H. U. (1981). On the mechanism of vesicle release from ATP-depleted human red blood cells. Biochim. Biophys. Acta 649, 462-470. doi: 10.1016/0005-2736(81)90437-5

Muratori, L., Muratori, P., Zauli, D., Grassi, A., Pappas, G., Rodrigo, L., et al. (2001). Antilactoferrin antibodies in autoimmune liver disease. Clin. Exp. Immunol. 124, 470-473. doi: 10.1046/j.1365-2249.2001.01524.x

Murphy, J. R. (1973). Influence of temperature and method of centrifugation on the separation of erythrocytes. J. Lab. Clin. Med. 82, 334-341.

Nagababu, E., Ramasamy, S., Rifkind, J. M., Jia, Y., and Alayash, A. I. (2002). Sitespecific cross-linking of human and bovine hemoglobins differentially alters oxygen binding and redox side reactions producing rhombic heme and heme degradation. Biochemistry 41, 7407-7415. doi: 10.1021/bi0121048

Nagura, Y., Tsuno, N. H., Ohkawa, R., Nojiri, T., Tokuhara, Y., Matsuhashi, M., et al. (2013). Inhibition of lysophosphatidic acid increase by prestorage whole blood leukoreduction in autologous CPDA-1 whole blood. Transfusion 53, 3139-3148. doi: $10.1111 /$ trf. 12152

Nässberger, L., Hultquist, R., and Sturfelt, G. (1994). Occurrence of anti-lactoferrin antibodies in patients with systemic lupus erythematosus, hydralazine-induced lupus, and rheumatoid arthritis. Scand. J. Rheumatol. 23, 206-210. doi: 10.3109/03009749409103062

Nguyen, D., Wagner-Britz, L., Maia, S., Steffen, P., Wagner, C., Kaestner, L., et al. (2011). Regulation of phosphatidylserine exposure in red blood cells. Cell. Physiol. Biochem. 28, 847-856. doi: 10.1159/000335798

Paesano, R., Berlutti, F., Pietropaoli, M., Pantanella, F., Pacifici, E., Goolsbee, W., et al. (2010). Lactoferrin efficacy versus ferrous sulfate in curing iron deficiency and iron deficiency anemia in pregnant women. Biometals 23, 411-417. doi: 10.1007/s10534-010-9335-z

Paesano, R., Pietropaoli, M., Gessani, S., and Valenti, P. (2009). The influence of lactoferrin, orally administered, on systemic iron homeostasis in pregnant women suffering of iron deficiency and iron deficiency anaemia. Biochimie 91, 44-51. doi: 10.1016/j.biochi.2008.06.004

Pantaleo, A., Ferru, E., Giribaldi, G., Mannu, F., Carta, F., Matte, A., et al. (2009). Oxidized and poorly glycosylated band 3 is selectively phosphorylated by Syk kinase to form large membrane clusters in normal and G6PD-deficient red blood cells. Biochem. J. 418, 359-367. doi: 10.1042/BJ20081557

Peen, E., Almer, S., Bodemar, G., Ryden, B. O., Sjolin, C., Tejle, K., et al. (1993). Antilactoferrin antibodies and other types of ANCA in ulcerative colitis, primary sclerosing cholangitis, and Crohns disease. Gut 34, 56-62. doi: 10.1136/gut.34.1.56

Phelan, H. A., Gonzalez, R. P., Patel, H. D., Caudill, J. B., Traylor, R. K., Yancey, L. R., et al. (2010). Prestorage leukoreduction ameliorates the effects of aging on banked blood. J. Trauma 69, 330-337. doi: 10.1097/TA.0b013e3181e0b253

Piccinini, G., Minetti, G., Balduini, C., and Brovelli, A. (1995). Oxidation state of glutathione and membrane proteins in human red cells of different age. Mech. Ageing Dev. 78, 15-26. doi: 10.1016/0047-6374(94)01511-J

Pietraforte, D., Matarrese, P., Straface, E., Gambardella, L., Metere, A., Scorza, G., et al. (2007). Two different pathways are involved in peroxynitrite-induced senescence and apoptosis of human erythrocytes. Free Radic. Biol. Med. 42, 202-214. doi: 10.1016/j.freeradbiomed.2006.10.035

Piomelli, S., and Seaman, C. (1993). Mechanism of red blood cell aging: relationship of cell density and cell age. Am. J. Hematol. 42, 46-52. doi: 10.1002/ajh.2830420110

Ramachandran, M., and Abraham, E. C. (1989). Age-dependent variation in the cytosol/membrane distribution of red cell protein kinase-C. Am. J. Hematol. 31, 69-70. doi: 10.1002/ajh.2830310116

Rettig, M. P., Low, P. S., Gimm, J. A., Mohandas, N., Wang, J., and Christian, J. A. (1999). Evaluation of biochemical changes during in vivo erythrocyte senescence in the dog. Blood 93, 376-384.

Rifkind, J. M., and Nagababu, E. (2013). Hemoglobin redox reactions and red blood cell aging. Antioxid. Redox Signal. 18, 2274-2283. doi: 10.1089/ars.2012.4867

Rifkind, J. M., Ramasamy, S., Manoharan, P. T., Nagababu, E., and Mohanty, J. G. (2004). Redox reactions of hemoglobin. Antioxid. Redox Signal. 6, 657-666. doi: $10.1089 / 152308604773934422$

Rumsby, M. G., Trotter, J., Allan, D., and Michell, R. H. (1977). Recovery of membrane micro-vesicles from human erythrocytes stored for transfusion: a mechanism for the erythrocyte discocyte-to-spherocyte shape transformation. Biochem. Soc. Trans. 5, 126-128.

Salhany, J. M., Cordes, K. S., and Sloan, R. L. (2001). Characterization of immunoglobulin binding to isolated human erythrocyte membranes: evidence for selective, temperature-induced binding of naturally occurring autoantibodies to the cytoskeleton. Biochim. Biophys. Acta 1511, 168-180. doi: 10.1016/S0005-2736(01)00280-2

Salzer, U., Hinterdorfer, P., Hunger, U., Borken, C., and Prohaska, R. (2002). $\mathrm{Ca}^{++}$-dependent vesicle release from erythrocytes involves stomatin-specific lipid rafts, synexin (Annexin VII), and sorcin. Blood 99, 2569-2577. doi: 10.1182/blood.V99.7.2569

Salzer, U., Zhu, R., Luten, M., Isobe, H., Pastushenko, V., Perkmann, T., et al. (2008). Vesicles generated during storage of red cells are rich in the lipid raft marker stomatin. Transfusion 48, 451-462. doi: 10.1111/j.15372995.2007.01549.x

Samaja, M., Rubinacci, A., De Ponti, A., and Portinaro, N. (1989). The effect of in vitro and in vivo cellular aging on the active calcium transport in human inside-out red cell membrane vesicles. Biochem. Biophys. Res. Commun. 159, 432-438. doi: 10.1016/0006-291X(89)90010-7

Sass, M. D. (1968). Glutathione synthesis in cell-free preparations from erythrocytes of different ages. Clin. Chim. Acta 22, 207-210. doi: 10.1016/00098981(68)90359-8

Schafer, F. Q., and Buettner, G. R. (2001). Redox environment of the cell as viewed through the redox state of the glutathione disulfide/glutathione couple. Free Radic. Biol. Med. 30, 1191-1212. doi: 10.1016/S0891-5849(01)00480-4

Schlüter, K., and Drenckhahn, D. (1986). Co-clustering of denatured hemoglobin with band 3: its role in binding of autoantibodies against band 3 to abnormal and aged erythrocytes. Proc. Natl. Acad. Sci. U.S.A. 83, 6137-6141. doi: 10.1073/pnas.83.16.6137 
Schweizer, E., Angst, W., and Lutz, H. U. (1982). Glycoprotein topology on intact human red blood cells reevaluated by cross-linking following amino-group supplementation. Biochemistry 21, 6807-6818. doi: 10.1021/bi00269a029

Sen, N., Spitzer, A. R., and Chander, A. (1997). Calcium-dependence of synexin binding may determine aggregation and fusion of lamellar bodies. Biochem. J. 322(Pt 1), 103-109.

Sharma, R., Singhal, S. S., Cheng, J., Yang, Y., Sharma, A., Zimniak, P., et al. (2001). RLIP76 is the major ATP-dependent transporter of glutathione-conjugates and doxorubicin in human erythrocytes. Arch. Biochem. Biophys. 391, 171-179. doi: 10.1006/abbi.2001.2395

Snyder, L. M., Leb, L., Piotrowski, J., Sauberman, N., Liu, S. C., and Fortier, N. L. (1983). Irreversible spectrin-haemoglobin crosslinking in vivo: a marker for red cell senescence. Br. J. Haematol. 53, 379-384. doi: 10.1111/j.13652141.1983.tb02038.x

Song, C. S., Park, D. I., Yoon, M. Y., Seok, H. S., Park, J. H., Kim, H. J., et al. (2012). Association between red cell distribution width and disease activity in patients with inflammatory bowel disease. Dig. Dis. Sci. 57, 1033-1038. doi: 10.1007/s10620-011-1978-2

Sorette, M. P., and Clark, M. R. (1991). Specificity of autologous antibody binding to phenylhydrazine-treated human erythrocytes-implications for models of red blood cell aging. J. Lab. Clin. Med. 117, 477-484.

Srivastava, S. K., and Beutler, E. (1969). The transport of oxidized glutathione from the erythrocytes of various species in the presence of chromate. Biochem. J. 114, 833-837.

Suzuki, T., and Dale, G. L. (1987). Biotinylated erythrocytes: in vivo survival and in vitro recovery. Blood 70, 791-795.

Teegen, B., Niemann, S., Probst, C., Schlumberger, W., Stocker, W., and Komorowski, L. (2009). DNA-bound lactoferrin is the major target for antineutrophil perinuclear cytoplasmic antibodies in ulcerative colitis. Ann. N.Y. Acad. Sci. 1173, 161-165. doi: 10.1111/j.1749-6632.2009.04752.x

Tiffert, T., Daw, N., Etzion, Z., Bookchin, R. M., and Lew, V. L. (2007). Age decline in the activity of the $\mathrm{Ca}^{+}{ }^{+}$-sensitive $\mathrm{K}^{+}$channel of human red blood cells. J. Gen. Physiol. 129, 429-436. doi: 10.1085/jgp.200709766

Tissot, J. D., Rubin, O., and Canellini, G. (2010). Analysis and clinical relevance of microparticles from red blood cells. Curr. Opin. Hematol. 17, 571-577. doi: 10.1097/MOH.0b013e32833ec217

Towbin, H., Staehelin, T., and Gordon, J. (1979). Electrophoretic transfer of proteins from polyacrylamide gels to nitrocellulose sheets: procedure and some applications. Proc. Natl. Acad. Sci. U.S.A. 76, 4350-4354. doi: 10.1073/pnas.76.9.4350

Turrini, F., Arese, P., Yuan, J., and Low, P. S. (1991). Clustering of integral membrane proteins of the human erythrocyte membrane stimulates autologous IgG binding, complement deposition, and phagocytosis. J. Biol. Chem. 266, 23611-23617.

Turrini, F., Mannu, F., Arese, P., Yuan, J., and Low, P. S. (1993). Characterization of the autologous antibodies that opsonize erythrocytes with clustered integral membrane proteins. Blood 81, 3146-3152.

Turrini, F., Mannu, F., Cappadoro, M., Ulliers, D., Giribaldi, G., and Arese, P. (1994). Binding of naturally occurring antibodies to oxidatively and nonoxidatively modified erythrocyte band 3. Biochim. Biophys. Acta 1190, 297-303. doi: 10.1016/0005-2736(94)90087-6

Vitturi, D. A., Sun, C. W., Harper, V. M., Thrash-Williams, B., Cantu-Medellin, N., Chacko, B. K., et al. (2013). Antioxidant functions for the hemoglobin beta93 cysteine residue in erythrocytes and in the vascular compartment in vivo. Free Radic. Biol. Med. 55, 119-129. doi: 10.1016/j.freeradbiomed.2012.11.003
Wagner-Britz, L., Wang, J., Kaestner, L., and Bernhardt, I. (2013). Protein kinase Calpha and P-type Ca channel CaV2.1 in red blood cell calcium signalling. Cell. Physiol. Biochem. 31, 883-891. doi: 10.1159/000 350106

Walder, J. A., Chatterjee, R., Steck, T. L., Low, P. S., Musso, G. F., Kaiser, E. T., et al. (1984). The interaction of hemoglobin with the cytoplasmic domain of band 3 of the human erythrocyte membrane. J. Biol. Chem. 259, $10238-10246$.

Waugh, S. M., and Low, P. S. (1985). Hemichrome binding to band 3: nucleation of Heinz bodies on the erythrocyte membrane. Biochemistry 24, 34-39. doi: 10.1021/bi00322a006

Weiss, G., and Goodnough, L. T. (2005). Anemia of chronic disease. N. Engl. J. Med. 352, 1011-1023. doi: 10.1056/NEJMra041809

Wiener, E., Hughes-Jones, N. C., Irish, W. T., and Wickramsinghe, S. N. (1986). Elution of anti-spectrin antibodies from red cells in homozygous b-thalassemia. Clin. Exp. Immunol. 63, 680-686.

Willekens, F. L., Roerdinkholder-Stoelwinder, B., Groenen-Dopp, Y. A., Bos, H. J., Bosman, G. J., van den Bos, A. G., et al. (2003). Hemoglobin loss from erythrocytes in vivo results from spleen-facilitated vesiculation. Blood 101, 747-751. doi: 10.1182/blood-2002-02-0500

Willekens, F. L., Werre, J. M., Kruijt, J. K., Roerdinkholder-Stoelwinder, B., Groenen-Dopp, Y. A., van den Bos, A. G., et al. (2005). Liver Kupffer cells rapidly remove red blood cell-derived vesicles from the circulation by scavenger receptors. Blood 105, 2141-2145. doi: 10.1182/blood-200404-1578

Winslow, R. M., and Intaglietta, M. (2008). Red cell age and loss of function: advance or SNO-job? Transfusion 48, 411-414. doi: 10.1111/j.15372995.2008.01657.x

Zimecki, M., Wieczorek, Z., Manzurier, J., and Spik, G. (1995). Lactoferrin lowers the incidence of positive Coombs' test in New Zealand black mice. Arch. Immunol. Ther. Exp. (Warsz) 43, 207-209.

Zipser, Y., Piade, A., Barbul, A., Korenstein, R., and Kosower, N. S. (2002). Ca ${ }^{2+}$ promotes erythrocyte band 3 tyrosine phosphorylation via dissociation of phosphotyrosine phosphatase from band 3. Biochem. J. 368, 137-144. doi: 10.1042/BJ20020359

Conflict of Interest Statement: The authors declare that the research was conducted in the absence of any commercial or financial relationships that could be construed as a potential conflict of interest.

Received: 30 October 2013; paper pending published: 18 November 2013; accepted: 09 December 2013; published online: 25 December 2013.

Citation: Lutz HU and Bogdanova A (2013) Mechanisms tagging senescent red blood cells for clearance in healthy humans. Front. Physiol. 4:387. doi: 10.3389/fphys. 2013.00387

This article was submitted to Membrane Physiology and Membrane Biophysics, a section of the journal Frontiers in Physiology.

Copyright (c) 2013 Lutz and Bogdanova. This is an open-access article distributed under the terms of the Creative Commons Attribution License (CC BY). The use, distribution or reproduction in other forums is permitted, provided the original author(s) or licensor are credited and that the original publication in this journal is cited, in accordance with accepted academic practice. No use, distribution or reproduction is permitted which does not comply with these terms. 